\title{
An Investigation of Plutonium Concentration and Distribution in Burrowing Crayfish from the White Oak Creek Floodplain
}

\author{
Martha S. Delaney \\ Roger C. Dahlman \\ Robert B. Craig
}

Environmental Sciences Division

Publication No. 1281 


\section{DISCLAIMER}

This report was prepared as an account of work sponsored by an agency of the United States Government. Neither the United States Government nor any agency Thereof, nor any of their employees, makes any warranty, express or implied, or assumes any legal liability or responsibility for the accuracy, completeness, or usefulness of any information, apparatus, product, or process disclosed, or represents that its use would not infringe privately owned rights. Reference herein to any specific commercial product, process, or service by trade name, trademark, manufacturer, or otherwise does not necessarily constitute or imply its endorsement, recommendation, or favoring by the United States Government or any agency thereof. The views and opinions of authors expressed herein do not necessarily state or reflect those of the United States Government or any agency thereof. 


\section{DISCLAIMER}

Portions of this document may be illegible in electronic image products. Images are produced from the best available original document. 
Printed in the United States of America. Available from National Technical Information Service

U.S. Department of Commerce

5285 Port Royal Road, Springfield, Virginia 22161

Price: Printed Copy $\$ 6.50 ;$ Microfiche $\$ 3.00$

This report was prepared as an account of work sponsored by an agency of the United States Government. Neither the United States Government nor any agency thereof, nor any of their employees, contractors, subcontractors, or their employees, makes any warranty, express or implied, nor assumes any legal liability or responsibility for any third party's use or the results of such use of any information, apparatus, product or process disclosed in this report, nor represents that its use by such third party would not infringe privately owned rights. 
ORNL/TM-6702

Contract No. W-7405-eng-26

AN INVESTIGATION OF PLUTONIUM CONCENTRATION AND

DISTRIBUTION IN BURROWING CRAYFISH FROM

THE WHITE OAK CREEK FLOODPLAIN

Martha S. Delaney, Roger C. Dahlman, and Robert B. Craig

Environmental Sciences Division

Publication No. 1281

$x_{0}$

Submitted as a thesis by Martha S. Delaney to the Graduate Council of the University of Tennessee in partial fulfillment of the requirements for the degree of Master of Science.

Date Published - JANUARY 1979

OAK RIDGE NATIONAL LABORATORY

Oak Ridge, Tennessee 37830

operated by

UNION CARBIDE CORPORATION

for the

DEPARTMENT OF ENERGY
NOTICE

This report was prepared as an eccount of work United Stntes united States Govemment. Neither the Energy, nor any of their emplates Departmeilt of contractors, subcontractors, of theis, nor any of their any warranty, express or impled, er asloyees, makes liability or responsibility for the or assumes any legal or usefulness of any informat the accuracy, completeness process dissersed in or ormation, apparatus, product or infringe privately owned resents that its use would not 
THIS PAGE

\section{WAS INTENTIONALLY LEFT BLANK}




\section{ACKNOWLEDGMENTS}

Throughout the study the senior author was assisted by several other personnel of the Oak Ridge National Laboratory whose surnames include Auerbach, Bogle, Brantley, Brinkley, Brocksen, Cerling, Cox, Dye, Foster, Francis, Frank, Goff, Gooch, Griffith, Herbes, Holbrook, Janzen, Jones, Kitchings, Kuhns, Littleton, McFadden, McLean, Merritt, Saylor, Scott, Sealand, Settle, Shanks, Shugart, Simmons, Smiddy, Stooksbury, Tamura, Tarr, Thompson, Trabalka, Tucker, Ward, Wilson, and Witherspoon.

For their confidence and encouragement, albeit long distance, the senior author's parents and family members are graciously aknowledged. The senior author would like to extend her gratitude to Donald Paine of Rockwell-Hanford Operations for sending his collection of reprints on crayfish to her and for advice during development of her research proposal. From Savannah River Ecology Laboratory, James Thorpe is recognized for his suggestions on maintaining radioactive crayfish indoors. 
THIS PAGE

\section{WAS INTENTIONALLY \\ LEFT BLANK}


DELANEY, M. S., R. C. DAHLMAN, and R. B. CRAIG. 1978. An investigation of plutonium concentration and distribution in burrowing crayfish from the White Oak Creek floodplain. ORNL/TM-6702. Oak Ridge National Laboratory, Oak Ridge, Tennessee. $120 \mathrm{pp}$.

The White 0ak Creek floodplain was contaminated with several radionuclides, including ${ }^{239} \mathrm{Pu}$, during the Manhattan Project in 1944. Plutonium distribution in the soil is nonhomogeneous. An investigation was conducted to determine $\mathrm{Pu}$ accumulation in a resident animal population. The investigation was necessary to evaluate potential Pu concentration in a food web. Crayfish were chosen because they complete their life-cycle within the contaminated environment, they directly contact contaminated muds, and they function in a food chain of significance to man.

Research focused on the concentration and distribution of ${ }^{239} \mathrm{Pu}$ in the crayfish from the White 0ak Creek floodplain. Thirty individuals were trapped, cleaned, dissected, and analyzed for ${ }^{230} \mathrm{Pu}$ content. Control crayfish from an area with fallout contamination were processed similarly.

Two major conclusions of the research were that $\mathrm{Pu}$ concentrations in contaminated crayfish typically exceed those of control crayfish by two orders of magnitude and that if an incident were to occur in which a standard man ingested the soft tissues of ten crayfish from the floodplain, an insignificant whole body dose would accrue over the subsequent 50 years of life. A predator would receive, on the average, between 5 and $10 \mathrm{dpm}{ }^{239} \mathrm{Pu}$ per gram of contaminated crayfish 
ingested. This would be true, whether or not the soft tissues and digestive tract were stripped from the carapace. The digestive tract of contaminated crayfish contained 21 to $33 \%$ of the Pu body burden, but the digestive tract represents only about $5 \%$ of the animal's biomass (dry wt.). Soft tissues contained 11 to $31 \%$ of the Pu body burden and represent 11 to $13 \%$ of the bodily mass. The analytical Pu determinations indicated that 48 to $62 \%$ of the Pu body burden of contaminated crayfish was associated with the carapace, and the carapace represents some $84 \%$ of the animal's biomass. Therefore, at a molt a large proportion of its accumulated $\mathrm{Pu}$ is deposited in the environment.

Additional field work included an investigation of population densities by counting crayfish burrow openings and by casting a burrow system to determine an average number of chimneys per crayfish. Apparently one primary tunnel with a chimney exists for each adult. The cast demonstrated that floodplain crayfish have access to several tunnel openings other than a vertical primary tunnel. The chimney density study was first used to estimate the population size of the contaminated crayfish and was later used to show the effect of the diversion of White 0ak Creek on the population.

A supplementary laboratory investigation using ${ }^{237} \mathrm{Pu}$ included a chronic Pu uptake study by uncontaminated crayfish. In those crayfish that had not fed on any ${ }^{237}$ Pu-spiked fish for several days before death, from 64 to $82 \%$ of the ${ }^{237} \mathrm{Pu}$ was associated with the body tissues. Complementary data for ${ }^{237} \mathrm{Pu}$ associated with the carapace ranged from 18 to $37 \%$ of the distribution. The concentration of 
${ }^{237} \mathrm{Pu}$ and its distribution in the body of these crayfish were compared with the concentration and distribution of ${ }^{239} \mathrm{Pu}$ from floodplain crayfish.

An inventory of ${ }^{239} \mathrm{Pu}$ in crayfish at two sites on the floodplain was calculated by multiplying the estimated biomass of the crayfish by their average ${ }^{239} \mathrm{Pu}$ concentration. This evaluation of Pu associated with the crayfish population was compared to an inventory of ${ }^{239} \mathrm{Pu}$ in the soil in which they burrow and was found to be eight orders of magnitude less. 
THIS PAGE

\section{WAS INTENTIONALLY LEFT BLANK}


TABLE OF CONTENTS

CHAPTER

PAGE

I. INTRODUCTION . . . . . . . . . . . . . . . . . 1

Hypothesis and Format of the Investigation . . . . . . 2

The Species ..................... 3

The Study Site..................... 8

Significance of the Investigation ........... 9

II. POPULATION STUDIES . . . . . . . . . . . . 15

Burrow Interconnectedness .............. 15

Chimney Density and Distribution ............ 18

Estimation of Population Sizes . . . . . . . . . . 24

III. CONCENTRATION AND DISTRIBUTION OF $239 \mathrm{Pu}$ IN CRAYFISH

Materials and Methods ............... 27

Results ... . ............ . . 30

Comparisons of $2399_{\mathrm{Pu}}$ in Crayfish and Their Environment . . 36

Inventory of $239 \mathrm{pu}$ at Two Contaminated Sites . . . . . . . 44

Radiation Doses ................. 47

IV. UPTAKE OF $237 \mathrm{Pu}$ BY CRAYFISH IN THE LABORATORY . . . . . . . . 53

Materials and Methods ............... 53

Results ................. . . 56

Absorption and Adsorption of $237 \mathrm{Pu}$........... 58

V. DISCUSSION . . . . . . . . . . . . . . 61

Comparison of Radionuclide Distributions in Three Species of Contaminated Crayfish in the Vicinity of White Oak Creek . 61

Comparison of ${ }^{239} \mathrm{Pu}$ Concentrations in Crayfish and Other.

Biota of the White Oak Creek Floodplain . . . . . 62

Biochemical Transfer of 239 py at Ecdys is ......... 63

Revisions in the Model of $239 \mathrm{Pu}$ in Crayfish ........ 65

VI. SUMMARY AND CONCLUSIONS . . . . . . . . . . . . 69

REFERENCES . . . . . . . . . . . . . . . . 72

APPENDIX A. TRAP SPECIFICATIONS •

APPENDIX B. ANALYSIS AND RESULTS OF $239 \dot{P}_{\mathrm{Pu}}$ IN CRAYFISH . . . . . . 85

APPENDIX C. CHARACTERISTICS OF $237 \mathrm{PU}$ AND OTHER PU ISOTOPES $: \cdot . \cdot 95$

APPENDIX D. GLOSSARY OF TERMS . . . . . . . . . . . . . . . 99 
THIS PAGE

\section{WAS INTENTIONALLY \\ LEFT BLANK}




\section{LIST OF TABLES}

TABLE

PAGE

1 Comparison of crayfish chimneys per quadrat (C/Q) at

Site 1 and Site 2 on the White Oak Creek floodplain

before and after the creek diversion......... 23

2 Comparison of crayfish chimney distribution at Site 1 and

Site 2 on the White Oak Creek floodplain before and after

the creek diversion .. . . . . . . . . . . 25

3 Mean concentrations of $239,240 \mathrm{pu}$ in components of contaminated and control crayfish $(x \pm s)$. . . . . . . 31

4 Concentrations and Relative Concentration Factors of $239 \mathrm{Pu}$ in components of crayfish from Site 1 , Site 2, and Site 3 . 32

5 Whole body distribution of mass and of ${ }^{239} \mathrm{Pu}$ in crayfish from Site 1, Site 2, and Site 3........... 34

6 Comparison of contaminated soil and crayfish from Site 1 and Site 2 in 1977 to fallout contaminated soil and crayfish from Site 3............. . . 35

7 Comparison of ${ }^{239} \mathrm{Pu}$ in soft tissues of crayfish and water from Site 1 and site 2 to ${ }^{239} \mathrm{Pu}$ in soft tissues of crayfish and water from Site 3 and Bioaccumulation Factors for soft tissues of crayfish relative to $239 \mathrm{Pu}$ in unfiltered and filtered $(0.22 \mathrm{~m})$ water samples from each site . . . . . 37

8 Concentration of ${ }^{239} \mathrm{Pu}$, Concentration Rat $10 \mathrm{~S}(\mathrm{CR})$, and the ${ }^{239} \mathrm{Pu}$ inventory of soil and crayfish from contaminated

Sites 1 and 2 on the White Oak Creek floodplain in 1977 . . 45

9 Estimated internal alpha radiation dose to crayfish body parts from ingestion of $239 \mathrm{Pu}_{\mathrm{u}}$............... 49

A-1 Dimensions of wooden trap pieces . . . . . . . . 82

B-1 The schedule of furnace temperatures $\left({ }^{\circ} \mathrm{C}\right)$ and the amount of time $(\mathrm{hr})$ to decarbonize and to dry ash prepared samples . 86

B-2 Compilation of analytical and statistical data for contaminated and control crayfish from three study sites for two years ..................... 92

C-1 Comparison of some physical characteristics of $\mathrm{Pu}$ iostopes used in this investigation .............. 96 
i

THIS PAGE

WAS INTENTIONALLY

LEFT BLANK 


\section{LIST OF FIGURES}

FIGURE

PAGE

1 Distinctive features of a Form I male Cambarus carolinus . . 5

2 Map indicating three study areas . . . . . . . . . 6

3 Graphic compartmental model of $\mathrm{Pu}$ movement through a

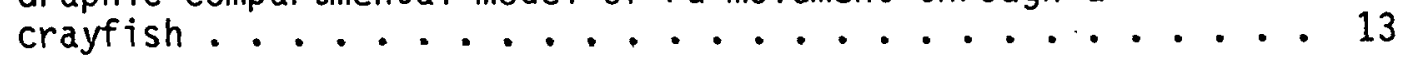

4 Schematic of the burrow cast . . . . . . . . . . 19

5 Schematic of the belt transect orientation for density study. with sample quadrats shaded . . . . . . . . . 22

6 Uptake of $237 \mathrm{Pu}(\mathrm{dpm})$ vs. time (days) . . . . . . . . 57

7 Graphic compartmental model of $\mathrm{Pu}$ movement through a crayfish indicating the interaction of soil with the carapace surface............... 66

8 Graphic compartmental model of Pu movement through a crayfish emphasizing the transfer of $\mathrm{Pu}$ from the carapace surface and the carapace to the digestive tract after ecdysis ...................... 68

A-1 An isometric projection of the crayfish trap . . . . . . 80 


\section{CHAPTER I}

\section{INTRODUCTION}

Plutonium is a valuable fuel for power generation, but skepticism as to its desirability as a nuclear fuel in the United States has developed. Due to its decay characteristics and its long effective half-life, the effects of alpha radiation from this man-made nuclide are considered potentially hazardous. Although ${ }^{239} \mathrm{Pu}$ does not occur naturally, small quantities are released to the environment from nuclear fue 1 reprocessing plants and nuclear weapons tests. Such emissions to aquatic and terrestrial ecosystems are low but detectable globally. Sediment, once suspended particulate matter, is the major repository for Pu that entered aquatic ecosystems by wastewater releases. Sorption of $\mathrm{Pu}$ to submerged surfaces is a dominant phenomenon in aquatic systems (Eyman and Trabalka, 1977). In terrestrial environments contamination has been caused largely by nuclear fallout. Results from several studies conducted on the uptake of $P_{u}$ by vegetation indicated that Pu was relatively immobile and retained by soil (Francis, 1973). The fundamental parameters for describing the behavior of $\mathrm{Pu}$ in natural animal populations, including its physical, chemical, and biological changes at various trophic levels, have not been sufficiently examined in the field. For Oak Ridge, Tennessee, data on the distribution and mobility of Pu in animal populations of contaminated ecosystems were limited quantitatively when this investigation was initiated. It is important to investigate a resident animal population of a historically contaminated ecosystem to determine the level of $\mathrm{Pu}$ accumulation 
because all the environmental influences on Pu cannot be completely simulated in a laboratory.

Hypothesis and Format of the Investigation

Crayfish were selected for study not only because they complete their life cycle within a contaminated zone but also because of their close contact with contaminated muds. Furthermore, crayfish function in a food chain of significance to man. Prior to this study, a census of the contaminated, burrowing crayfish on the White Oak Creek floodplain was not undertaken. Therefore, the level of Pu concentrated by the crayfish relative to the amount of $\mathrm{Pu}$ in the floodplain ecosystem was also unknown. However, it was hypothesized that the potential for the assimilation of $\mathrm{Pu}$ in the crayfish burrowing within the boundary of the White 0ak Creek floodplain would be elevated in comparison with crayfish from similar but uncontaminated ecosystems possibly due to differences in chemical changes or physical movement of $\mathrm{Pu}$ in their environment or to differences in physlology or behavior of the animals. Crayfish contacting or ingesting soil that had Pu adsorbed to it were hypothesized to collect Pu on the exterior surface of their carapaces and to assimilate $\mathrm{Pu}$ to some extent into their body tissues, including the inner layers of the carapace.

Whether predators of such contaminated crayfish ingested them whole or in part, Pu would then be mobilized into the food web, and the predator would receive some alpha radiation dose. Although $\mathrm{Pu}$ is not nearly so much a threat to man when ingested (rather than inhaled), Pu movement in the food web could possibly become more of a concern for 
man if such crayfish or some of their predators were cooked in the open air. It was necessary to determine whether Pu passes through the digestive tract without being absorbed or whether $\mathrm{Pu}$ is concentrated by the soft tissues or by the carapace of the crayfish in order to evaluate potential concentration by predators.

The study was partitioned into five tasks, including:

1. an estimation of the population size and density of the contaminated, burrowing crayfish,

2. a determination of the amount of ${ }^{239} \mathrm{Pu}$ in the digestive tracts, soft tissues, and carapaces of free-living Cambarus carolinus from the White 0ak Creek floodplain population,

3. a determination of $\mathrm{Pu}$ uptake by uncontaminated crayfish (using ${ }^{237} \mathrm{Pu}$ ) to evaluate chronic $\mathrm{Pu}$ uptake,

4. an evaluation of the proportion of the Pu to which the burrowing crayfish were exposed estimated to be bound by them, and

5. an estimation of the internal alpha radiation dose to the contaminated crayfish and to predators of such crayfish, including man, due to ingested ${ }^{239} \mathrm{Pu}$.

The Species

The primary burrowing crayfish inhabiting the floodplain are Cambarus (Jugicambarus) carolinus. The first description of the genus Cambarus was by Erichson (1846) and was updated by Hobbs (1965) for diagnostic purposes. Further information on this genus is available in Hobbs (1974). Hobbs gave a description of a newly proposed subgenus 
Jugicambarus in 1969 to encompass those members of the genus possessing a subrectangular chela with the mesial margin of the palm bearing a high ridge of fused tubercles ("cristiform row"). Additional description of both the subgenus and species is included not only in a key developed specifically for crayfish species of Tennessee by Bouchard (1972) but also in an emended description by Bouchard (1973).

Hobbs and Bouchard (1973) carefully traced all references to $\underline{C}$. carolinus through some ten revisions in its name in order to identify misapplications. In 1976, Bouchard and Hobbs reported the range of areola widths for this species as 13.7 to 39.3 times as long as broad. This species' coloration is usually bright red to a red orange. Adult females presumably molt only once a year, but adult males molt twice each year (Walton and Hobbs, 1971). Diagrams of the distinctive features of a Form I male $\underline{\text { C. }}$ carolinus are shown in Figure 1.

Bouchard (1974) described the range of $\underline{\mathcal{C}}$. carolinus as north from South Carolina, North Carolina, and Tennessee to the French Broad River System. Hobbs (1972) indicated that this species can be found burrowing in the mountains and foothills from Kentucky and Pennsyivania to Georgia and South Carolina. The range over which the species has been found is included as an insert in Figure 2; it is based on a map in an earlier work by Hobbs (1969). Dewees (1972) presented life history data on the species with notes referring to her work with it in Tennessee.

\section{Position in the Food Web}

Burrowing crayfish have a complicated foraging pattern. It is thought that their food base changes either with the availability of 
ORNL-OWG 77-12575

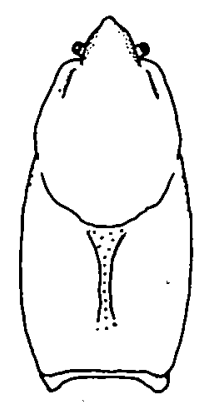

DORSAL VIEW OF THORACIC CARAPACE

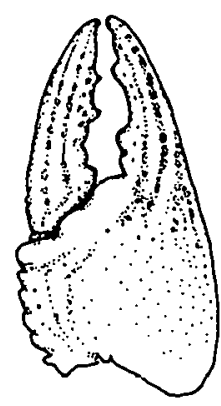

DORSAL VIEW OF. RIGHT CHELA

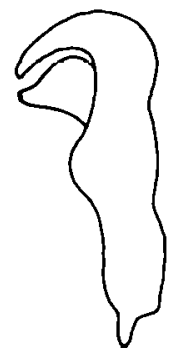

LATERAL VIEW OF FIRST PLEOPOD

Figure 1. Distinctive features of a Form I male Cambarus carolinus. In the dorsal view of the thoracic carapace, the narrow areola is delineated with a single row of punctations between the branchiocardiac grooves (concave impressions). In the dorsal view of the right chela, a fused row of cristiform tubercles appears on the mesial (left) margin of the palm of the chela. The lateral view of the first pleopod indicates the tapering central projection (uppermost terminal element). without a subapical notch. 


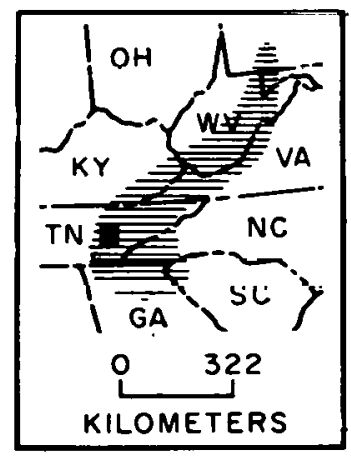

ORNL-DWG 77-45694R

BURIAL GROUND NO. 4
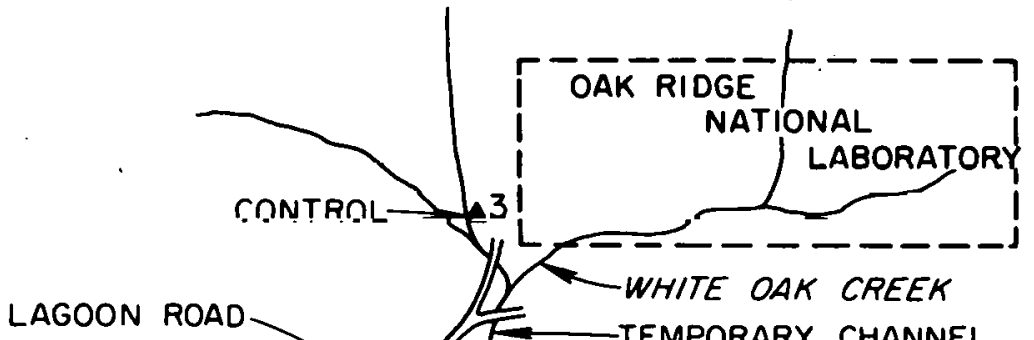

LAGOON ROAD

WHITE OAK CREEK

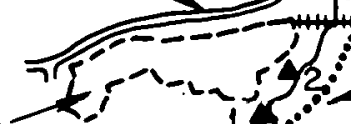

ORIGINAL CHANNEL

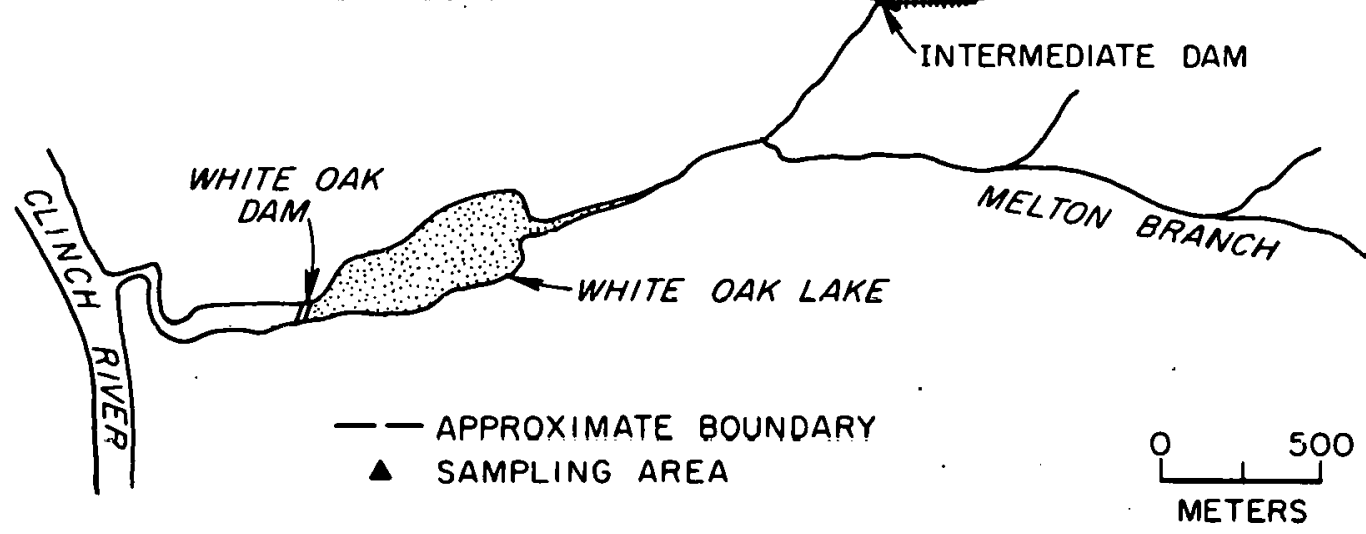

Figure 2. Map indicating three study areas. Site 1 and Site 2 are on the White Oak Creek floodplain. Site 3 is on a tributary of White 0ak Creek. Insert indicates range of Cambarus carolinus.

Source of insert: H. H. Hobbs, Jr. 1969. On the distribution and phylogeny of the crayfish genus Cambarus. pp. 93-178. In: P. C. Holt (ed.), The Distributional History of the Biota of the Southern Appalachians, Part I: Invertebrates. Virginia Polytechnic Institute, Research Division Monograph 7, Blacksburg, Virginia. 
the food on a seasonal basis or with the age and maturity of the crayfish. Prins (1968) described the food habits of Cambarus tenebrosus as 15 to $26 \%$ filamentous algae, $23 \%$ vascular aquatics, 8 to $14 \%$ animal, and 8 to 14\% detrital material. Since organic residues frequently contain elevated levels of nutrients and contaminants, there is an increased potential for the presence of $\mathrm{Pu}$ in the food web leading to crayfish. Crayfish prey on small bluegill (Penn, 1950) and earthworms, Lumbricus rubellus (personal observation). Crayfish are important in the detrital trophic level of food webs in that they ingest material which otherwise would be very slowly decomposed. Crayfish hold a key trophic position by serving as transformers of energy and nutrients into utilizable forms for animals and plants of other trophic levels in a community. Because of their polytrophic diet and their ability to utilize allochthonous sources of energy (Momot et al., 1978), crayfish increase the rate of movement and transfer of energy as well as nutrients.

Crayfish serve a multiplicity of roles in food webs. Crayfish serve as hosts to certain parasitic ostracods. C. carolinus host predominantly Dactylocythere chalaza and Ascetocythere asceta (Walton and Hobbs, 1971). Penn (1950) reviewed several papers to compile information on the food habits of fish, amphibians, and reptiles in the eastern United States. Crayfish are important in the diet of fish, turtles, and of many poikilothermal aquatic/semiaquatic vertebrates. Herons and ibises consume these crustaceans to varying degrees in their diets (Huner, 1976). Man, especially along the southern Coastal Plain, 
commonly consumes crayfish. Raccoons and opossums are among the recognized predators of $\underline{c}$. carolinus, and although transient, they are the most apt to be present on the floodplain. Owls are secondary predators.

The Study Site

Waste effluents containing small quantities of radioactive isotopes, following precipitation with soda ash, were released into White Oak Creek during the Manhattan Project in 1944. From the creek, ${ }^{239} \mathrm{Pu}$ and other radionuclides were deposited along the water course before flowing into an intermediate retention pond and eventually into White Oak Lake. The retention pond was drained later in 1944 . In the thirty year interim, a typical floodplain forest has developed over its three hectare area. The soil can be considered a recent alluvium, and the distribution of isotopes is nonhomogeneous. In the top twelve $\mathrm{cm}$ of soil, the concentration of $239,240 \mathrm{Pu}$ ranges from 55.5 to 333

$\mathrm{dpm} \mathrm{g}^{-1}$; the predominant oxidation state seems to be $\mathrm{Pu}$ (IV) (Dah Iman et al., 1976). The soil texture is a loamy clay (Auerbach et al., 1978).

The floodplain of White Oak Creek (Figure 2) is located approximately 0.8 to $1.2 \mathrm{~km}$ south of the West Portal of Oak Ridge National Laboratory (ORNL). One sampling site was chosen approximately 25 to bU $m$ west of the temporary channel for White Oak Creek near an earthen dam. A second sampling site was selected to the north, but about $200 \mathrm{~m}$ west of the temporary channel for White Oak Creek, in a grassy location of the floodplain. The control sampling site, contaminated with fallout radiation and with natural background radiation from indigenous radium 
and thorium, was not located on the floodplain, but rather along a tributary to White Oak Creek, north and west of the floodplain, that might have been influenced by a radiation burial ground in the area. The three sites are indicated in Figure 2.

\section{Significance of the Investigation}

\section{Molting}

Burrowing crayfish may sustain a supportive role in the turnover and redistribution of the transuranic nuclides in the floodplain ecosystem. Elements from a variety of sources in the area may accumulate in the carapace and could be redistributed at ecdysis, if the shed exoskeleton is abandoned. Schuster (1976) noted that molted exuviae were never found in burrows; apparently crayfish molt outside their burrows. After ecdysis, most of the shed exoskeleton is ingested. Should the carapace not be ingested, abandonment of carapace pieces outside burrows would effectively redistribute buried $\mathrm{Pu}$ to the ground surface.

Data on $\mathrm{Pu}$ in exoskeletons of $\underline{\mathrm{C}}$. carolinus were collected, as described in Chapter III and Appendix B. The proportion of the whole body burden shed, once or twice a year for the adults, then either ingested or abandoned, and the implications of each, are reported and discussed in the third and fifth chapters, respectively.

Stevenson (1969) identified sclerotin (a protein cross-linked with quinones) in the crayfish cuticle. More recently, he carefully described the molting cycle of crayfish (1974). He discusses a shift in the chitin synthesis pathway at ecdysis. Before the molt, when the 
inner layers of the old cuticle are being digested, the crayfish uses acetylglucosamine, in preference to glucose, as a precursor for chitin. After the molt, any acetylglucosamine that was liberated from the digestion of the chitin is available for synthesis of new chitin. An experiment with a ${ }^{14} \mathrm{C}$-acetylglucosamine confirmed that much of the new chitin is made from old chitin (Gwinn and Stevenson, 1973). When the supply of acetylglucosamine is no longer available, the animal feeds to obtain glucoes.

Whether there is a similar phenomenon simultaneously occurring for $\mathrm{Pu}$, a temporary transposition of $\mathrm{Pu}$ from the calcified exoskeleton to the body tissues until the new carapace is synthesized, has not been studied. Further, it has not been the focus of this investigation. It is, however, a consideration in the realm of radiation ecology, and the concept will be mentioned again in the fifth chapter.

\section{Radioactivity}

Some studies have been completed regarding the concentration of various radioactive isotopes in crayfish. Schurr and Stamper (1962) noted that uptake of ${ }^{85} \mathrm{Sr}$ was enhanced in recently molted crayfish; more than $90 \%$ was found in the exoskeleton. In studying the same problem at Ohio State University, Momot noted that 55 to $80 \%$ of the available ${ }^{85} \mathrm{Sr}$ was retained in the body tissues after a molt in the young-of-the-year of a different species (unpublished). Tanner (1964) found that crayfish taken from white 0 ak Creek had ${ }^{60} \mathrm{Co},{ }^{106} \mathrm{Ru}$, and ${ }^{137} \mathrm{Cs}$ associated with their exoskeletons. These data reflect the importance of the crayfish exoskeletons in concentrating various isotopes. 
Crayfish (0.5 to $0.8 \mathrm{~kg}$ wet wt. per sample) from the Great Miami River concentrated $\mathrm{Pu}$ in tissues rather than in the sclerotized carapace (Wayman et al., 1975). Bartelt et al. (1977) reported that concentrations of ${ }^{238} \mathrm{Pu}$ in over 800 crayfish from the Great Miami River were much higher in tissues than in shells. In the reports by Wayman et al. (1975) and Bartelt et al. (1977), no data were given for the digestive tracts separately. Perhaps the "tissue" fraction includes the digestive tract.

Aarkrog (1971) reported that shells of shrimp normally contained more ${ }^{239} \mathrm{Pu}$ than did flesh. He did not specify whether the digestive tract was included in the flesh analyses. Ward (1966) studied lobsters (Homarus vulgaris) and determined that up to $89.5 \%$ of the total ${ }^{239} \mathrm{Pu}$ was located in the calcified exoskeleton. Flesh contained only $1.2 \%$ of the total $\mathrm{Pu}$ in the body. The ${ }^{239} \mathrm{Pu}$ had been available to the lobsters only through the sea water in which they were kept. Although she never stated the actual number of lobsters analyzed, a figure in the report implies that her data are from less than ten lobsters. In the crab (Cancer pagurus) some $77.5 \%$ of the $\mathrm{Pu}$ accumulated by the crab was localized in the gills (Guary et al., 1976), representing a surface for direct contact with sea water. The exoskeleton fixed $5.9 \%$ of the Pu radioactivity, which is present in an insoluble form in a marine environment.

Prior to the present investigation, it had not been determined whether Pu accumulates in the exoskeleton or in the body tissues of $\underline{\mathrm{C}}$. carolinus. If $\mathrm{Pu}$ is predominantly in the carapace, then when the animal molts, a packet of $\mathrm{Pu}$ is left behind in one small zone (if the carapace 
is abandoned). On the other hand, if there is assimilation of $\mathrm{Pu}$ into all the edible tissues of the crayfish body, then any predators will receive a relatively high alpha radiation dose following either partial or complete ingestion of the crayfish.

Since this species resides in a soil habitat, it was important that the edibie tissues of the crayfish be analyzed separately for an assessment to be made of the probable hazards to some of its potential predators, including man. The constitution of the edible tissues varies for the type of predator. One type of predator, including owls, probably ingests the entire crayfish. Later a bolus of indigestible portions might be disgorged. Another type of predator, including raccoons, consumes the soft tissues and the digestive tract. People would probably ingest only the soft tissues, primarily muscle.

Isotopes can enter crayfish not only via food pathways but also by water intake occurring through the mouth and gills and by soil contact or ingestion. It is important to determine which of these three possible inputs is the major contributor to the amount of $\mathrm{Pu}$ in crayfish. This study was not designed to answer that particular question; however, a graphic compartmental model has been constructed to interpret various sources of information contributing to the understanding of Pu movement in $\underline{\text { C. }}$ carolinus (Figure 3 ).

A model that clarifies an understanding of a problem, that reveals the more important parameters to measure, or that assists in predictions of future events is considered successfur (Patten, 1972; Craig and Rudd, 1974). The model in Figure 3 was meant to be heuristic in order to outline the prominent features of the movement of ${ }^{239} \mathrm{Pu}$ with respect 
ORNL-DWG 78-12686

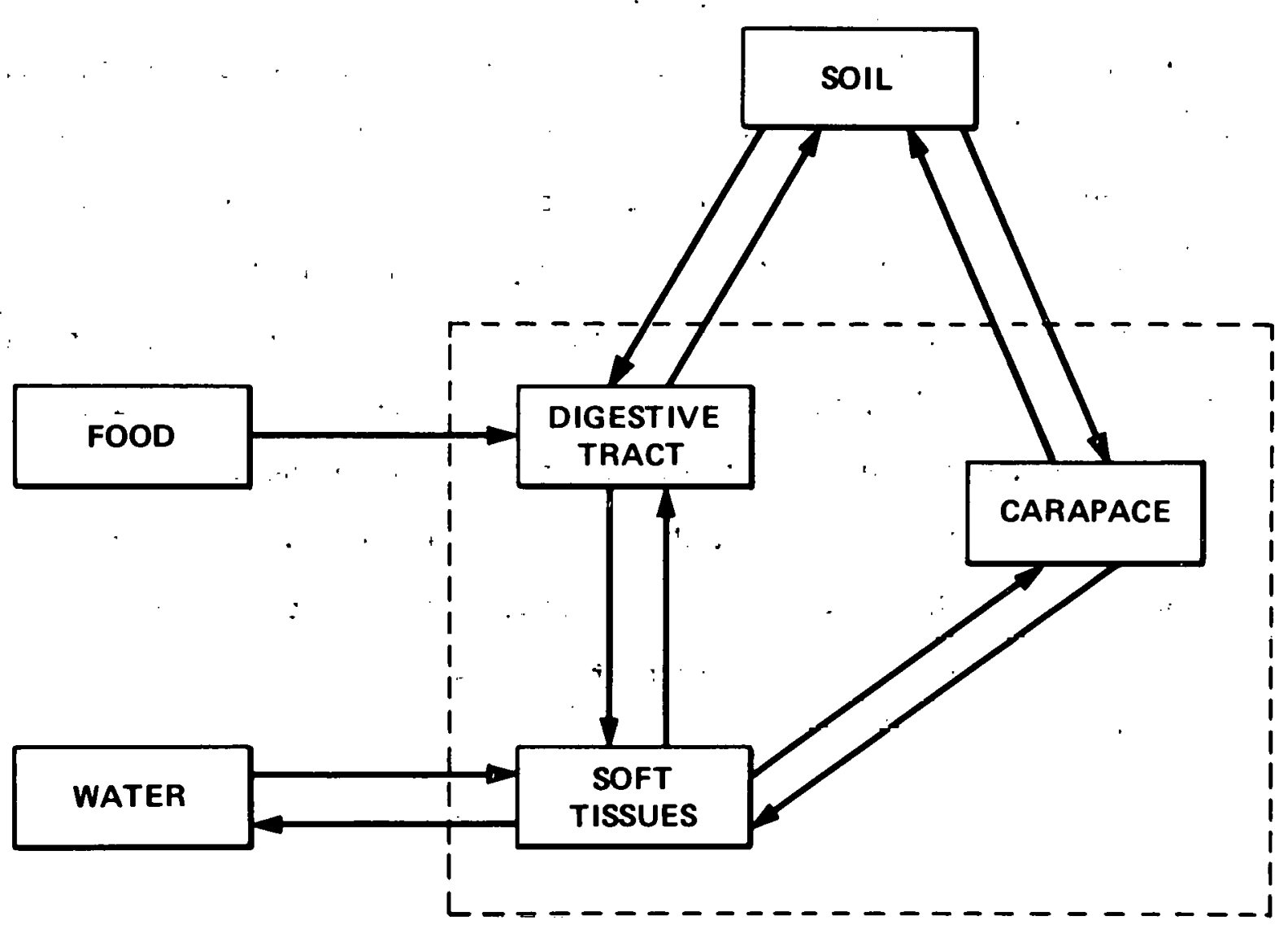

Figure 3. Graphic compartmental model of Pu movement through a crayfish. The three components of the crayfish are enclosed by the broken lines. 
to a floodplain crayfish. Potential sources of Pu for a floodplain crayfish are included as compartments external to the crayfish. Each of the internal compartments represents a different route for uptake of $\mathrm{Pu}$ including ingestion, filtration, or direct contact of contaminated soil.

The model has been the focus of some of the studies included in the overall investigation. For example, because the rate of Pu transfer to the crayfish from its food had not yet been determined, an experiment to estimate the rate of $\mathrm{Pu}$ uptake by uncontaminated crayfish was conducted. This laboratory experiment is reported in Chapter IV.

The model was not meant to be predictive; rather, it is descriptive of $\mathrm{Pu}$ uptake, assimilation, and elimination by the crayfish for the purpose of understanding these events and their relationships. Indirectly, however, others studying the movement of $\mathrm{Pu}$ in food webs might gain insights from this model. Some of the notions might be transferable to scavengers of other food webs. 
CHAPTER II

POPULATION STUDIES

The habitat of Cambarus carolinus is the interface of soil and fresh water. Bliss (1968) mentioned that C. carolinus burrow in wet pastures and in swampy areas. Schuster (1976) observed that some burrows of a crayfish species within the Jugicambarus subgenus were in areas where the water table was four to five feet below the surface. Burrow construction involved a primary tunnel perpendicular to the surface which branched; secondary tunnels converged with it to form an upper and a lower chamber. There are usually at least two openings to the surface, and a passageway may descend to a depth of about three feet. If the water table is deeper than three feet below the ground surface, the excavation is extended until water is reached. Apparently the water table sets the lower boundary for the living chamber. For $\underline{C}$. carolinus, Hobbs (1970) implied that the burrows, while branching, remain nearly vertical. Dewees (1972) discussed the habitat and burrows of the species. However, she did not know the extent of interconnectedness of the tunnels.

\section{Burrow Interconnectedness}

For the purposes of this study, if two different tunnels led to a common chamber, whether or not a lower chamber was adjoined, only connectedness would be described. Limited interconnectedness would be demonstrated by two or three neighboring tunnels leading to at least two distinct chambers that were connected. The existence of several 
tunnels, chambers, and passageways in contiguity would indicate interconnectedness. Rather than risk the destruction of one or more tunnels, chambers, or passageways by digging, it was decided that a plaster of Paris or cement cast should be made of a cluster of burrow openings at one of the floodplain study sites to determine if systems were interconnected.

It was expected that a cast of the burrow cluster would generate two kinds of information. Adult and juvenile crayfish were expected to evacuate the burrows as cement was poured. Data on the numbers of crayfish and the openings from which they emerged were expected to indicate the number of crayfish per chimney. In this way, it was hoped that a rough estimate of the subpopulations' numbers could be calculated based on the number of chimneys found in a sample of observational units.

To some extent, the style of trapping was expected to be influenced by the results of the burrow cast. Under conditions of connectedness, a crayfish that had to leave the burrow for food would have an almost equal probability of entering or avoiding a trap if only one chimney of a set had a trap over it. With progressively more interconnectedness, the probability of a crayfish not entering a trap would increase unless several traps were placed over neighboring chimneys in a cluster.

\section{Materials and Methods}

For the burrow cast, a slurry of cement, plaster of Paris, and water was used. A commercial sugar (CFR-1) was added to the mixture (a few grains per liter of slurry) to maintain pouring consistency and to 
prevent the mixture from setting before it had flowed into all the crevices of the burrow system. Dried cement was heavy, yet it provided the durability that the plaster lacked. A portable generator was carried to the location (Site 2) to provide the power for the finger pump which was used to control the flow into narrow tunnels.

A six foot long piece of rubber tubing was inserted into the widest burrow opening in a cluster found at Site 2. The other end was inserted into the bucket of the cement mixture, and the finger pump was attached at a convenient length along the tubing. Within a few moments after the pump was turned on, the slurry began moving from the bucket through the tubing and into the burrow. After the first tunnel filled, the tube was transferred to the nearest tunnel opening. This procedure was repeated until every opening to the bank was filled with the slurry. The cast was allowed to solidify for a week before excavation with hand trowels began.

Result.s

The cement and plaster mixture was firm at all the chimney openings a week after the cast was poured, However, inner portions of the cast had not hardened. A second problem with the excavation was that the chimneys broke because they were not supported by soil and they were fragile in spite of the cement.

Three primary openings to the burrows came up to the ground level. Six smaller openings were found along the bank. An additional chimney was discovered during the excavation because its base was filled with 
the mixture. The entire cast was sketched in Figure 4 to represent the arrangement of the chambers, vertical tunnels, and horizontal passageways.

Dimensions of the three primary burrow tunnels, those which came to the ground level, were $48 \mathrm{~cm}, 99 \mathrm{~cm}$, and $82 \mathrm{~cm}$, if Figure 4 is examined from left to right. Cast cement was measured with a flexible metric tape measure. The long axis of the largest chamber, located approximately central in Figure 4 , was $38 \mathrm{~cm}$.

During the activities prior to the actual cast pouring, three crayfish were observed. The crayfish were not seen simultaneously; however, physical features such as size, unequal chelae, or a broken antenna were noticeable. Two crayfish were still recognizable in the cement of the cast. The locations are marked in Figure 4.

Because cement was not directly poured into secondary tunnels, several passages were merely lined with the mixture as gravity influenced it. During excavation it was possible to follow a tunnel even if cement indicated only its origin or connection to a chamber or passageway. Some of the cement slurry reached the water table in either a chamber or in a passageway.

\section{Chimney Density and Distribution}

The chimneys of these creatures are frequently observed and discussed. Chimneys occur where heaps of mud are piled to one side of a burrow opening on the soil surface. Dewees (1972) observed chimneys at about half the openings to a burrow. For this study, crayfish chimneys and other burrow openings without chimneys were counted with the 


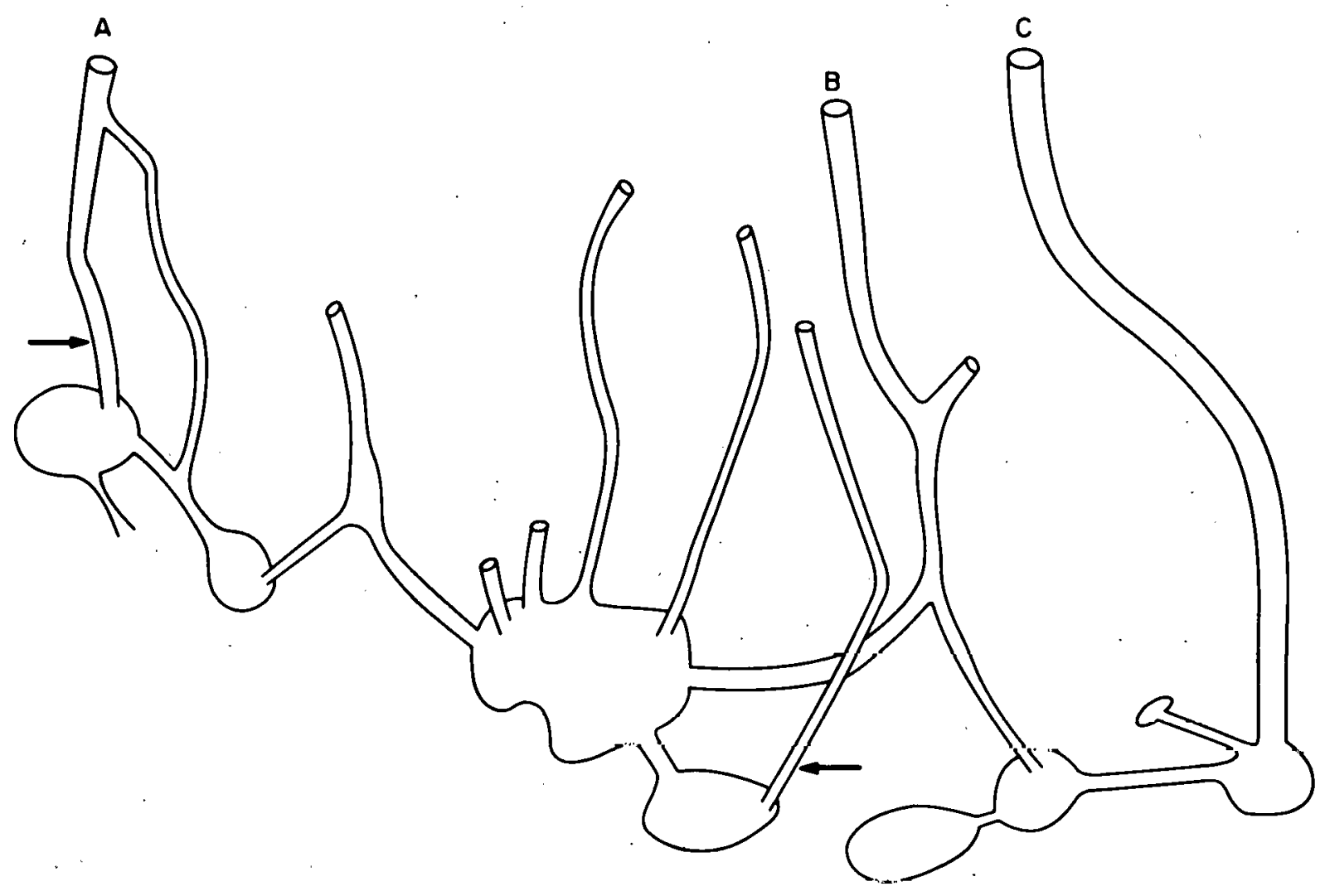

Figure 4. Schematic of the burrow cast. Locations of encased crayfish are marked by bold arrows. Primary tunnels to the ground surface are marked by $A, B$, or $C$. Tunnels, chambers, and passageways are approximately in proportion to each other, but linear dimensions are not precise. 
intention that the results be used in conjunction with the burrow cast to estimate the relative density and size of the two sampled subpopulations of crayfish from the White Oak Creek floodplain. Two other objectives involved with the chimney counting were to describe the density of crayfish chimneys at Site 1 and Site 2 with respect to a source of intermittently flowing water at each site and to quantify statistically a decrease in the number of chimneys over the course of a year (personal observation).

\section{Methods}

A wooden frame hinged at its four right angles and containing an area of one square meter was used as a quadrat marker for counting chimneys. A table of random numbers was used to generate pairs (coordinates) indicating the transect and quadrat number to be observed. A belt transect was used as if a stem count of a plant population was being recorded. Site 1 and Site 2, as indicated in Figure 2 (p. 6), were bulh used for this study.

By preliminary observation. it was noted that. r.rayfish chimneys were crowded near the banks of the intermittently flowing streams leading to White Oak Creek. Arrangement of the chimneys appeared stratified with respect to distance from each stream. Several burrow openings could be found close to the bank of a stream, and active chimneys (fresh mud, well repaired) were sometimes found paired with another opening further from any apparent flowing surface water. The method of analyzIng population density and its arrangement was stratified sampling with a nested sampling design on three levels as described by Bancroft and 
Brindley (1958). Sampling sites for the subpopulations were chosen randomly from the floodplain network of streams. Secondly, the transects were oriented (with a random origin) parallel to the banks of the stream at each site; adjacent transects were similarly oriented. Finally, square meter quadrats were selected randomly. The sampling scheme is sketched in Figure 5.

At the designated quadrat, the frame was set in place, vegetation was either lifted or cleared away, and chimneys or obvious openings without chimneys were counted and recorded. At either site, the transects were not more than four meters from the bank. Counts were made at three quadrats per transect; four transects were marked on each side of a stream. On one bank at Site 2 only one quadrat per transect was counted due to the thick, thorny vegetation growing there. No openings in the channel of either stream were counted; however, chimneys found on the banks were included in the counts of the $0-1 \mathrm{~m}$ transect. The chimney counting was first done during the autumn of 1976 and was repeated using somewhat different quadrats in November $19 / /$.

\section{Result.s}

Chimneys were distributed in a similar pattern at both sites. With respect to distance from a stream, 42 to $45 \%$ of the chimneys could be found within one meter of the stream bank; 16 to $17 \%$ in the second meter; 25 to $32 \%$ in the third meter; and 10 to $14 \%$ in the fourth meter from a stream (Table 1). These percentages represent data compiled from the two floodplain sampling sites in 1976 and 1977 at about the same time each year ( 1 ate autumn). 


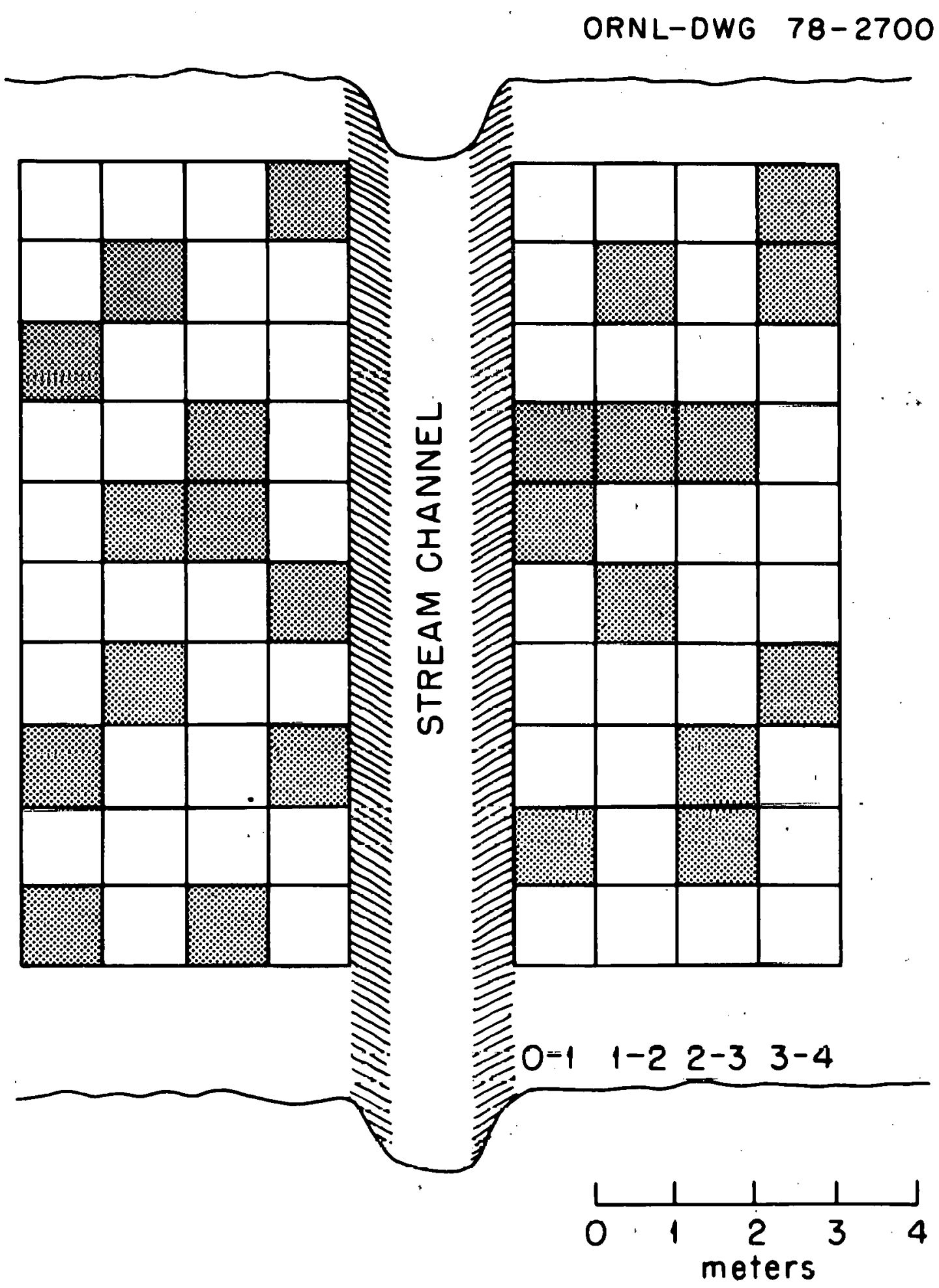

Figure 5. Schematic of the belt transect orientation for density study with sample quadrats shaded. 
Table 1. Comparison of crayfish chimneys per quadrat $(C / Q)$ at Site 1 and Site 2 on the White Oak Creek floodplain before and after the creek diversion

\begin{tabular}{|c|c|c|c|c|c|c|c|}
\hline \multirow[b]{2}{*}{ Transect } & \multirow[b]{2}{*}{ Site } & \multicolumn{3}{|c|}{1976} & \multicolumn{3}{|c|}{1977} \\
\hline & & $n^{a}$ & $C / Q \pm 1$ & S.D. & $n^{a}$ & $C / Q \pm 1$ & S.D. \\
\hline \multirow[t]{2}{*}{$0-1 \mathrm{~m}$} & 1. & 6 & 5.67 & 3.01 & 6 & 3.33 & 1.51 \\
\hline & 2 & 4 & 3.00 & 1.41 & 4 & 2.25 & 1.26 \\
\hline \multirow[t]{2}{*}{$1-2 m$} & 1 & 3 & 2.67 & 2.89 & 6 & 1.17 & 1.47 \\
\hline & 2 & 4 & 1.00 & 0.82 & 4 & 1.00 & 0.82 \\
\hline \multirow[t]{2}{*}{$2-3 m$} & .1 & 3 & 4.67 & 0.58 & 6 & 1.33 & 1.51 \\
\hline & 2 & 4 & 2.50 & 1.00 & 4 & 2.00 & 1.41 \\
\hline \multirow[t]{2}{*}{$3-4 m$} & 1 & 6 & 1.17 & 1.17 & 6 & 0.83 & 1.33 \\
\hline & 2 & 3 & 1.00 & 1.00 & 4 & 1.00 & 0.82 \\
\hline
\end{tabular}

${ }^{a}$ Number of quadrats $\left(m^{2}\right)$ sampled. 
Since chimneys were recorded for two consecutive years, a comparison of data was possible. The tallies are compiled in Table 2. At Site 1 a 49\% decrease in the number of chimneys between 1976 and 1977 was recorded. At Site 2 the decrease in chimneys per square meter averaged $11 \%$ for the same two years.

\section{Estimation of Population Sizes}

The hurrow cast demonstrated that crayfish have access lo inany tunnel openings other than a vertical primary tunnel. Possibly one primary vertical tunnel with a chimney exists for each adult. Since several openings to a burrow system are clustered within a meter of the stream bank, it can be concluded that crayfish live in colonies in this zone. Several tunnels and passageways connected at enlarged chambers 20 to $30 \mathrm{~cm}$ below the ground surface, depending on the water table level.

Actual chimney counts in quadrats indicate that openings further than one meter from a stream are usually paired. It is suspected that a passageway might exist to connect tunnels further from flowing surface water to the part of the system nearer to intermittently flowing water.

An estimate for the size of the two subpopulations was made. According to the results of the burrow cast in which three crayfish were observed within ten tunnels, the $0-1 \mathrm{~m}$ transects are assumed to have three holes per adult. Since the adults of $\underline{c}$ carolinus usually have at least two chimneys (Dewees, 1972), information from the chimney count data indicates that a population of between 95 and 124 crayfish existed at Site 1 in 1976. For Site 2, using the combined results of 
Table 2. Comparison of crayfish chimney distribution at Site 1 and Site 2 on the White 0ak Creek floodplain before and after the creek diversion

\begin{tabular}{|c|c|c|c|c|c|c|}
\hline \multirow[b]{2}{*}{ Site } & \multirow[b]{2}{*}{ Transect } & \multicolumn{2}{|r|}{1976} & \multicolumn{2}{|r|}{1977} & \multirow{2}{*}{$\begin{array}{l}\text { Percent } \\
\text { Change }\end{array}$} \\
\hline & & $n^{a}$ & Chimneys & $n^{a}$ & Chimneys & \\
\hline \multirow[t]{4}{*}{1} & $0-1 \mathrm{~m}$ & 6 & 34 & 6 & 20 & -41 \\
\hline & $1-2 \mathrm{~m}$ & 3 & 8 & 6 & 7. & -56 \\
\hline & $2-3 m$ & 3 & .14 & 6 & 8 & -71 \\
\hline & 3-4 m & 6 & 7 & 6 & 5 & -29 \\
\hline \multirow[t]{5}{*}{2} & $0-1 \mathrm{~m}$ & 4 & 12 & 4 & 9 & -25 \\
\hline & $1-2 m$ & 4 & 4 & 4 & 4 & 0 \\
\hline & $2-3 m$ & 4 & 10 & 4 & 8 & -20 \\
\hline & $3-4 \mathrm{~m}$ & 3 & 3 & 4. & 4 & 0 \\
\hline & Total & 33 & 92 & 40 & 65 & -42 \\
\hline
\end{tabular}

$a_{\text {Number of quadrats }}\left(\mathrm{m}^{2}\right)$ sampled. 
the number of chimneys per quadrat, the distribution of the chimneys with respect to a stream, and the number of chimneys per crayfish, a population size of 45 to 60 adult or near-adult crayfish was calculated for 1976. In 1977 the data from Site 1 indicated 44 to 55 animals. Similarly 40 to 55 crayfish were active at Site 2.

The crayfish population at both sites decreased from 1976 to 1977. Data from Table 2 was used to test the null hypothesis $\mathrm{H}_{0}: C / Q_{76}=\mathrm{C} / \mathrm{Q}_{77}$. The Paired $\mathrm{t}$ Statistic, which is sensitive to changes in couplets, was used. With eight paired observations, the $C / Q_{76}$ was significantly different from $C / Q_{77}(P<0.05)$. The number of crayfish trapped at Site 1 in 1976 accounts for a 13 to $17 \%$ decrease in the population. However, the average decrease for the site was $49 \%$ (Table 2). Similarly, Site 2 trap results account for only a 7 to $9 \%$ decrease in the estimated population. The causative factor for the decrease in population at the two sites may have been the diversion of White 0ak Creek in June, 1977. The creek channel was turned aside to its former course (Figure 2, p. 6) as a waste management mitigation procedure to abate any movement of contaminated materials from a nearby waste disposal area. After the diversion, some crayfish may have moved closer to the water rather than remain in their dry burrow systems. 
CHAPTER III

\section{CONCENTRATION AND DISTRIBUTION \\ OF ${ }^{239}$ PU IN CRAYFISH}

Levels of ${ }^{239} \mathrm{Pu}$ in cleaned crayfish trapped from the White 0ak Creek floodplain (Site 1 and Site 2, Figure 2, p. 6) and from the control area (Site 3) were determined quantitatively. By comparing relative masses of dissected body parts to the amount of ${ }^{239} \mathrm{Pu}$ detectable in each, the whole body distribution of the radionuclide in the crayfish was determined. Samples not only of soil from crayfish chimneys but also of water from the small streams at the three sites were analyzed for ${ }^{239} \mathrm{Pu}$. Therefore, ${ }^{239} \mathrm{Pu}$ concentrations in crayfish from the three sites were related to two of the environmental media with which the animals interact.

\section{Materials and Methods}

\section{Trapping}

A trap was designed to attract individual crayfish from burrow openings such that the burrow system was not destroyed and the animal was not killed. Details of the trap design and construction are given in Appendix A. Since crayfish feed nocturnally, overnight sampling was propitious. Baited traps were aligned over fresh chimneys and checked the following day. Captured animals were placed in labeled plastic bags which were sealed and promptly frozen at the work area near the floodplain. Crayfish were trapped during early autumn of 1976 and late spring and summer, 1977. 
Sample Preparations and Analyses

Crayfish were defrosted, scrubbed, sonically washed, and microscopically inspected for soil. Each crayfish was dissected such that the digestive tract component included the esophagus, stomach, and intestine; soft tissues accounted for the muscles, gills, nerves, and other organs; and the carapace fraction included the complete exoskeleton.. The amount of ${ }^{239} \mathrm{pu}_{\mathrm{u}}$ in a single crayfish was expected to be too low to be detected with any statistical significance. Therefore, digestive tracts, soft tissues, or carapaces of up to seven crayfish were combined for analysis. Details of cleaning, drying, ashing, and analyzing and counting for ${ }^{239} \mathrm{Pu}$ have been recorded in Appendix $B$.

To a detector, ${ }^{239} \mathrm{Pu}$ and ${ }^{240} \mathrm{Pu}$ are indistinguishable with respect to energy (Table $\mathrm{C}-1$, Appendix $\mathrm{C}$ ). Therefore, ${ }^{239} \mathrm{Pu}$ has been used in this and subsequent discussion to refer to both isotopes. A known amount ( $5 \mathrm{dpm}$ ) of ${ }^{242} \mathrm{Pu}$ was added to each sample as an internal standard to verify recovery. Values for ${ }^{239} \mathrm{Pu}$ were calculäted with respect to the amount of ${ }^{242} \mathrm{Pu}$ detected in the sample after all procedures for analys is were performed, such that

$242 \mathrm{pu}$ counts : $5 \mathrm{dpm} 242 \mathrm{pu}:: 239 \mathrm{pu}$ counts : $X \mathrm{dpm} 239 \mathrm{pu}$

and the amount of ${ }^{239} \mathrm{Pu}$ detected was divided by the dry weight of the sample (digestive tract, soft tissues, or carapace). Error was attributable either (a) to physical error in weighing samples, (b) to an error in pipetting the ${ }^{242} \mathrm{Pu}$ spike $( \pm 2 \%)$, or (c) to counting error. An error term to describe the indeterminate error in radioactivity measurement was calculated, such that 
$\frac{\sqrt{239} \mathrm{Pu} \text { counts }}{{ }^{239} \mathrm{Pu} \text { counts }} \quad\left({ }^{239} \mathrm{Pu} \mathrm{dpm} \mathrm{g^{-1 }}\right)=s\left(\mathrm{dpm} \mathrm{g}^{-1}\right)$.

The equation (Eq. 3-2) was approximated from

$242 \mathrm{pu}$ counts $\pm \sqrt{242 \mathrm{pu} \text { counts }}: 5 \mathrm{dpm} 242 \mathrm{pu}:$ :

${ }^{239} \mathrm{Pu}$ counts $\pm \sqrt{239 \mathrm{Pu} \text { counts }}: \mathrm{X} \mathrm{dpm}{ }^{239} \mathrm{Pu}$,

with modifications to include the sample dry weight.

In order to compare the concentration of ${ }^{239} \mathrm{Pu}$ in the floodplain crayfish to the concentration of ${ }^{239} \mathrm{Pu}$ in crayfish not exposed to contaminated soil or:water, four crayfish were taken from the control area (Site 3) and prepared as were the others. The same freezer, washing solution, sonifier, microscope, tools, balance, and ovens were used to process the control sample. It was solubilized, spiked, concentrated, extracted, and counted for Pu side by side with floodplain crayfish samples.

Soil samples from Site 1 and Site 2 served as a basis for comparing ${ }^{239} \mathrm{Pu}$ cóncentrations in floodplain crayfish to their environment. Chimneys from burrow excavations were taken as soil samples. Eight fresh chimneys were air dried, sifted to remove litter and rocks, and placed in widemouthed plastic jars. After 10 stainless steel ball bearings $(0.5 \mathrm{~cm}$ diam) were inserted, $j$ ars were sealed with caps and tape, covered with plastic bags, and sealed again. Samples were placed on a ball mill for $72 \mathrm{hr}$ to pulverize soil. The eight samples were then sent to the Analytical Chemistry Division (ORNL) for determination of the level of ${ }^{239} \mathrm{Pu}$ in a $10 \mathrm{~g}$ subsample. 
Because water was a possible source for some ${ }^{239} \mathrm{Pu}$ in the crayfish, two unfiltered water samples (1 liter) were taken from each of the three field sites as indicated in Figure $2(p, 6)$. One sample of each pair was filtered using a Millipore Filter of $0.22 \mu \mathrm{m}$. All six samples were sent to the Analytical Chemistry Division (ORNL) for acidification and analys is of ${ }^{239} \mathrm{Pu}$ in a $500 \mathrm{ml}$ subsample.

\section{Resulțs}

Concentration of ${ }^{239} \mathrm{Pu}$ in Crayfish

Mean concentrations of $239,240 \mathrm{Pu}$ found in analyzed contaminated and control crayfish are presented in Table 3. For the crayfish at each site, the total mass (dry wt.) of the components of a crayfish and the average of the ${ }^{239} \mathrm{Pu}$ concentrations for the components are reported in Table 4 . The average ${ }^{239} \mathrm{Pu}$ concentration in crayfish components from Site 3 was based on one composite sample for each component; therefore, no standard deviations were calculated.

Mean values of ${ }^{239} \mathrm{Pu}$ in contaminated and control crayfish were based on raw analytical data compiled in Table B-2 (Appendix B)! The 0.05 level of significance, a statistical error of counting measurement, is reported in Table B-2 for every sample of contaminated cray. fish. In that factor, there is a $95 \%$ chance that an error in a specific determination (due to stray counts at energies higher or lower than those used to detect ${ }^{239} \mathrm{Pu}$ ) would be smaller than the percent error listed in the table (Chase and Rabinowitz, 1962). 
Table 3. Mean concentrations of $239,240 \mathrm{Pu}$ in components of contaminated and control crayfish $\left(\bar{x} \pm s^{a}\right)$

\begin{tabular}{|c|c|c|c|}
\hline Crayfish & $n^{b}$ & Component & $\begin{array}{c}\text { Mean Pu concentration } \\
\left(\mathrm{dpm} \mathrm{g}^{-1}\right)\end{array}$ \\
\hline \multirow[t]{3}{*}{ Contaminated } & 30 & Digestive tract $^{c}$ & $6.5: \pm 0.29$ \\
\hline & & Soft tissues & \pm 0.065 \\
\hline & & Carapace & $0.67 \pm 0.024$ \\
\hline \multirow[t]{3}{*}{ Control } & 4 & Digestive tract $^{c}$ & $0.044 \pm 0.020$ \\
\hline & & Soft tissues & $0.014 \pm 0.0057$ \\
\hline & & Carapace & $0.0034 \pm 0.00086$ \\
\hline
\end{tabular}

$a_{s}=$ average of standard deviations based on counting error.

$b_{n}=$ number of crayfish analyzed.

${ }^{c}$ With contents. 
Table 4. Concentrations and Relative Concertration Factors of ${ }^{239} \mathrm{Pu}$ in components of crayfish from Site 1 , site $\bar{c}$, and Site 3

\begin{tabular}{|c|c|c|c|c|c|c|}
\hline Crayfish & Site & $r^{a}$ & Comjonent & $\begin{array}{l}\text { Total mass } \\
\text { (g dry wt.) }\end{array}$ & $\begin{array}{l}\text { Average of }{ }^{233} \mathrm{PL} \\
\text { concentrations } \\
\left(\begin{array}{l}\left.\text { dpm g } g^{-1}\right) \\
\left(\bar{x} \pm s^{b}\right)\end{array}\right.\end{array}$ & $\begin{array}{l}\text { Relative Concentration } \\
\text { Factor }\end{array}$ \\
\hline \multirow[t]{6}{*}{ Contaminated } & 1 & $\tilde{c} 1$ & Digestive tract $^{d}$ & 3.304 & $7.482 \pm 5.409$ & $(-0.023$ to 2.023$)$ \\
\hline & & & Soft tissues & 6.719 & $1.326 \pm 0.812$ & $0.177(0.009$ to 0.345$)$ \\
\hline & & & Carミpace & 52.229 & $0.927 \pm 0.412$ & $0.124(0.019$ to 0.229$)$ \\
\hline & 2 & 9 & Jigest-ve tract $^{d}$ & 1.313 & $5.221 \pm 3.869$ & $(-0.048$ to 2.048$)$ \\
\hline & & & joft tissues & 2.852 & $0.610 \pm 0.409$ & $0.117(0.000$ to 0.234$)$ \\
\hline & & & Larapace & 21.766 & $0.344 \pm 0.22 i$ & $0.666(0.001$ to 0.131$)$ \\
\hline \multirow[t]{3}{*}{ Control } & 3 & 7 & Digestive =ract ${ }^{c}$ & 0.473 & 0.044 & 1 \\
\hline & & & Soft tissues & 2.220 & 0.014 & 0.318 \\
\hline & & & Carapace & 14.308 & 0.003 & 0.068 \\
\hline
\end{tabular}

$a_{n}=$ number of crayfish analyzed.

$\mathrm{b}_{\mathrm{s}}=$ standard deviation of the $239 \mathrm{Pu}$ corcentrations.

$\mathrm{c}_{\text {Mean }}{ }^{239} \mathrm{Pu}$ corsentration in component/Mean ${ }^{239} \mathrm{Pu}$ concentration in digestive tract (range includes error terms).

${ }^{d}$ With contents. 
Whole Body Distribution of ${ }^{239} \mathrm{Pu}$

Values for the distribution of ${ }^{239} \mathrm{Pu}$ in contaminated crayfish from Site 1 and Site 2 were calculated by dividing the amount of ${ }^{239} \mathrm{Pu}$ in each crayfish component by the whole body burden of the crayfish from each contaminated site. The quotient was then converted to a percentage of the body burden. Values for the distribution of ${ }^{239} \mathrm{Pu}$ in contaminated and control crayfish (similarly calculated using a composite sample) are presented in Table 5.

For comparison of the ${ }^{239} \mathrm{Pu}$ distribution in the bodies of contaminated and control crayfish with the distribution of mass in the crayfish from each site, the total mass of each component analyzed is reported in Table 5. For the crayfish at each site, the whole body distribution of mass was calculated by dividing the amount of mass in a component by the mass of the whole body. The quotient was then converted to a percentage of the mass of the whole body.

Levels of ${ }^{239} \mathrm{Pu}$ in Environmental Media

Concentrations of ${ }^{239} \mathrm{Pu}$ in chimney soil samples from site 1 and Site 2, those that the floodplain crayfish contacted while burrowing, are compiled in Table 6 . Each of the values is compared to a mean ${ }^{239} \mathrm{Pu}$ concentration in soil samples with fallout contamination taken near Knoxville and Fort Loudon Dam and reported by Oakes et al. (1976). Whole body concentrations of ${ }^{239} \mathrm{Pu}$ in crayfish from the two floodplain sites are listed in Table 6 also. Each of these whole body ${ }^{239} \mathrm{Pu}$ levels is compared to the concentration of ${ }^{239} \mathrm{Pu}$ in crayfish from the control area (Site 3 ). 
Table 5. Whole body distribution of mass and of ${ }^{239} \mathrm{Pu}$ in crayfish from Site 1 , site 2 , and site 3

\begin{tabular}{|c|c|c|c|c|c|c|}
\hline Crayfish & Site & Component & $\begin{array}{l}\text { Total mass } \\
(\mathrm{g}) \\
\text { in component }\end{array}$ & $\begin{array}{l}\text { Mass distrijution } \\
\text { (percent of whole } \\
\text { body mas.s.) }\end{array}$ & $\begin{array}{l}\text { Total }{ }^{239} \mathrm{Pu} \\
\text { (dpm) in } \\
\text { component }\end{array}$ & $\begin{array}{l}{ }^{239} \mathrm{Pu} \text { distribution } \\
\text { (percent of whole } \\
\text { body } 239 \mathrm{pu} \text { ) }\end{array}$ \\
\hline \multirow[t]{8}{*}{ Contaminated } & 1 & Digestive tract & 3.304 & 5.3 & 19.957 & 26.3 \\
\hline & & Scft tissues & 6.719 & 10.8 & 8.509 & 11.2 \\
\hline & & Carapace & 52.229 & 83.9 & 47.387 & 62.5 \\
\hline & & Whole body & 62.252 & 100.0 & 75.853 & 100.0 \\
\hline & 2 & Digestive tract & 1.313 & 5.1 & 5.235 & 32.7 \\
\hline & & Soft tissues & 2.852 & 11.0 & 1.908 & 11.9 \\
\hline & & Carapare & 21.766 & 83.9 & 8.363 & 55.4 \\
\hline & & Whole body & 25.931 & 100.0 & 16.006 & 100.0 \\
\hline \multirow[t]{4}{*}{ Control } & 3 & Digestive tract & 0.473 & 2.8 & 0.021 & 20.8 \\
\hline & & Soft $t \div$ ssues & 2.220 & 13.0 & 0.031 & 30.7 \\
\hline & & Carapace & 14.308 & 84.2 & 0.049 & 48.5 \\
\hline & & Whole trody & 17.001 & 100.0 & 0.101 & 100.0 \\
\hline
\end{tabular}


Table 6. Comparison of contaminated soil and crayfish from Site 1 and Site 2 in 1977 to fallout contaminated soi ${ }^{a}$ and crayfish from Site 3

\begin{tabular}{|c|c|c|}
\hline Site & $\begin{array}{l}\text { Concentration of }{ }^{239} \mathrm{Pu} \\
\text { in soil }\left(\mathrm{dpm} \mathrm{g}^{-1}\right)\end{array}$ & 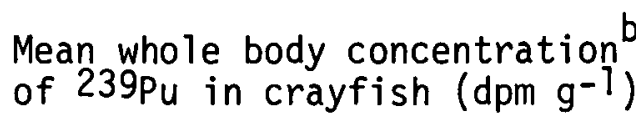 \\
\hline 1 & $4.8 \times 10^{1}$ & $7.28 \times 10^{-1}$ \\
\hline 2 & $1.0 \times 10^{2}$ & $7.48 \times 10^{-1}$ \\
\hline 3 & $4.1 \times 10^{-2^{a}}$ & $5.94 \times 10^{-3}$ \\
\hline $1 / 3$ & $1.2 \times 10^{3}$ & $1.23 \times 10^{2}$ \\
\hline $2 / 3$ & $2.4 \times 10^{3}$ & $1.26 \times 10^{2}$ \\
\hline
\end{tabular}

a Source: T. W. Oakes, K. E. Shank, and C. E. Easterly. 1976. Natural and man-made radionuclide concentrations in Tennessee soils. pp. 322-333. In: Tenth Midyear Topical Symposium of the Health Physics Society Northeastern New York Chapter.

$\mathrm{b}_{\text {Total }}{ }^{239} \mathrm{Pu}(\mathrm{dpm})$ in whole body/Total mass $(\mathrm{g})$ in whole body. 
Data of ${ }^{239} \mathrm{Pu}$ analyses for both unfiltered and filtered water samples from the three study sites are listed in Table 7. Results from unfiltered water samples were included because they represented the condition of the water to which the crayfish were exposed. Filtered water samples from each study site were all on the same order of magnitude regarding ${ }^{239} \mathrm{Pu}$ content $\left(10^{-5} \mathrm{dpm} \mathrm{m} \mathrm{m}^{-1}\right)$.

The average ${ }^{239} \mathrm{Pu}$ concentration (dpin $\mathrm{y}^{-1} \mathrm{dry}$ wl.) in the soft tissues of crayfish from each site are included in Table 7 . The ${ }^{23 \dot{9}} \mathrm{Pu}$ values in the soft tissues of crayfish from Site 1 and Site 2 are each compared to the ${ }^{239} \mathrm{Pu}$ value in the soft tissues of crayfish from Site 3. Similarly, ${ }^{239} \mathrm{Pu}$ concentrations in the unfiltered water samples from Site 1 and Site 2 are each compared to the ${ }^{239} \mathrm{Pu}$ concentration in the unfiltered water sample from Site 3. Filtered water samples were similarly compared. In the same table (Table 7), the ${ }^{239} \mathrm{Pu}$ concentrations in both unfiltered and filtered water samples were used to calculate Bioaccumulation Factors for the soft tissues of crayfish from the three study areas.

\section{Comparisons of ${ }^{239} \mathrm{pu}$ in Crayfish and Their Environment}

Average ${ }^{239} \mathrm{Pu}$ concentrations in components of contaminated crayfish for comparison with those of control crayfish have been reported in Table 3 (p. 31) based on the data of Table B-2 (Appendix B). Floodplain crayfish had between 110 and 255 times more ${ }^{239} \mathrm{Pu}$ associated with their digestive tracts than control crayfish had. For soft tissues, the range was between 55 and 110 times more ${ }^{239} \mathrm{Pu}$ in the 
Table 7. Comparison of ${ }^{239} \mathrm{Pu}$ in soft tissues of crayfish and water from Site 1 and Site 2 to ${ }^{239} \mathrm{Pu}$ in soft tissues of crayfish and water from Site 3 and Bioaccumulation Factors for soft tissues of crayfish relative to ${ }^{239} \mathrm{Pu}$ in unfiltered and filtered $(0.22 \mu \mathrm{m})$ water samples from each site

\begin{tabular}{|c|c|c|c|c|c|}
\hline \multirow[b]{2}{*}{ Site } & \multirow{2}{*}{$\begin{array}{l}\text { Average }{ }^{239} \mathrm{Pu} \\
\text { in soft tissues } \\
\left(\text { dpm } g^{-1}\right) \\
\left(\bar{x} \pm s^{a}\right)\end{array}$} & \multirow{2}{*}{$\begin{array}{c}{ }^{239} \mathrm{Pu} \text { in unfiltered } \\
\text { water } \\
\left.(\mathrm{dpm} \mathrm{m}]^{-1}\right) \\
\left.\text { ix } \pm \mathrm{s}^{\mathrm{b}}\right)\end{array}$} & \multirow{2}{*}{$\begin{array}{c}{ }^{239} \mathrm{Pu} \text { in filtered } \\
\text { water } \\
\left(\mathrm{dpm} \mathrm{ml}^{-1}\right) \\
\left(\bar{x} \pm \mathrm{s}^{\mathrm{b}}\right)\end{array}$} & \multicolumn{2}{|c|}{ Bioaccumulation Factor ${ }^{\mathrm{C}}$} \\
\hline & & & & $\begin{array}{l}\text { Unfiltered } \\
\text { water }\end{array}$ & $\begin{array}{l}\text { Filtered } \\
\text { water }\end{array}$ \\
\hline 1 & $1.326 \pm 0.812$ & $1.1 \pm 0.2 \times 10^{-3}$ & $6 \pm 5 \times 10^{-5}$ & $\begin{array}{c}1205 \\
(435 \text { to } 1975)\end{array}$ & $\begin{array}{c}22100 \\
(-751 \text { to } 44951)\end{array}$ \\
\hline 2 & $0.610 \pm 0.409$ & $9.6 \pm 2 \times 10^{-4}$ & $1 \pm 1 \times 10^{-5}$ & $\begin{array}{l}635 \\
(189 \text { to } 1081)\end{array}$ & $\begin{array}{c}61000 \\
(-12444 \text { to } 13444)\end{array}$ \\
\hline 3 & 0.014 & $<1 \times 10^{-5}$ & $<1 \times 10^{-5}$ & $>1400$ & $>1400$ \\
\hline $1 / 3$ & $94.7^{d}$ & $>110^{d}$ & $>6^{d}$ & & \\
\hline $2 / 3$ & $43.6^{c}$ & $>96^{d}$ & $>1^{d}$ & & \\
\hline
\end{tabular}

$a_{s}=$ standarc deviation of the ${ }^{239} \mathrm{Pu}$ concentrations.

$b_{s}=$ standarc deviation based on counting error.

${ }^{\mathrm{Pu}}$ (dpm $\mathrm{g}^{-1}$ dry wt.) in soft tissues/Pu (dpm ml $]^{-1}$ ) in water (range includes error terms). $d_{\bar{x} / \bar{x}}$. 
contaminated crayfish. The carapaces of the floodplain crayfish had about 165 to 250 times more ${ }^{239} \mathrm{Pu}$ associated with them than those of the control crayfish. Overall, the average ${ }^{239} \mathrm{Pu}$ concentrations were slightly more than one hundred times greater in floodplain crayfish. To describe the ${ }^{239} \mathrm{Pu}$ concentrations further, average ${ }^{239} \mathrm{Pu}$ concentrations in components of crayfish from Site 1, Site 2, and Site 3 have been listed in Table 4 (p. 32). In all cases, the concentration of ${ }^{239} \mathrm{Pu}$ (on a per gram basis) is greatest in the digestive tract component. The digestive tracts of crayfish from Site 1 and Site 2 had from 120 to 170 times more ${ }^{239} \mathrm{Pu}$ associated with them than those of the crayfish from Site 3 . In the soft tissues, the range was between 44 and 95 times more concentration in crayfish from Site 1 or Site 2. For carapaces, crayfish from the two floodplain study areas concentrated about 115 to 300 times more ${ }^{239} \mathrm{Pu}$ than crayfish from the control area.

These data indicate that the digestive tracts and carapaces have large differences in ${ }^{239} \mathrm{Pu}$ concentrations when contaminated crayfish are compared to control crayfish using either overall averages (Table 3, p. 31) or averages according to site (Table 4), as anticipated. One reason that the digestive tracts have so much ${ }^{239} \mathrm{Pu}$ (on a per gram basis) is the radioactive soil associated with them, since crayfish were not given time to clear their intestines completely. Although the crayfish were carefully cleaned of visible external soil, carapaces of contaminated crayfish probably were analyzed with some tenacious and microscopically imperceptible radioactive soil particles. To some extent, soil Pu passing through the digestive tract or touching the exterior carapace is an adsorbate. 
Whereas the physical adsorption of ${ }^{239} \mathrm{Pu}$ accounts for the large concentration differences in the digestive tracts and carapaces of contaminated crayfish in comparison with control crayfish, physical mechanisms offer only a partial explanation for the difference of one to two orders of magnitude in the ${ }^{239} \mathrm{Pu}$ concentrations between the soft tissues of floodplain crayfish and the soft tissues of control crayfish. One mechanism for ${ }^{239} \mathrm{Pu}$ to become associated with the soft tissues is by filtration of water by the gills. This physical mechanism for ${ }^{239} \mathrm{Pu}$ adsorption could account for some of the concentration differences between contaminated and control crayfish. The biochemical penetration of ${ }^{239} \mathrm{Pu}$ from the tissues of the digestive tract to the soft tissues is probabiy not greater than about $10^{-3} \%$ (Dahlman et al., 1976). The fraction of ${ }^{239} \mathrm{Pu}$ transfer occurring from the epidermal layer of the carapace to the soft tissues is unknown. Biological mechanisms of ${ }^{239} \mathrm{Pu}$ transfer to the soft tissues from the digestive tract or from the carapace, as well as from the soft tissues to the digestive tract or to the carapace, considerably complicate the concentration differences that are strictly explanable by physical mechanisms.

With the rationale that most ${ }^{239} \mathrm{Pu}$ enters the crayfish body by ingestion, each of the components was set in proportion to the digestive tract; the ratio has been entitled the Relative Concentration Factor for this study. The Relative Concentration Factors indicate the proportion of the ${ }^{239} \mathrm{Pu}$ received at least partially from the digestive tract. Standard deviations about the mean of the ${ }^{239} \mathrm{Pu}$ concentrations for each component were included in calculating the Relative Concentration Factors using an equation for division of quantities 
$A$ and $B$ which include errors $a$ and $b$ respectively (Chase and Rabinowitz, 1962):

$(A \pm a) /(B \pm b)=(A / B)\left(1 \pm \sqrt{\frac{a^{2}}{A^{2}}+\frac{b^{2}}{B^{2}}}\right)$

The Relative Concentration Factors in Table 4 (p. 32) indicate that the ${ }^{239} \mathrm{Pu}$ concentration in the digestive tracts of all and lyzed crayfish were 8 to 15 times greater than the ${ }^{239} \mathrm{Pu}_{\mathrm{u}}$ concentration in the carapace (on a per gram basis). The soft tissues of contaminated crayfish had 1.4 to 1.8 times more ${ }^{239} \mathrm{Pu}$ (per gram) than the carapace, but the data for control crayfish indicate that the ${ }^{239} \mathrm{Pu}$ concentration in the soft tissues exceeded the ${ }^{239} \mathrm{Pu}$ concentration in the carapace by a factor of almost five. The soft tissues of control crayfish apparently received ${ }^{239} \mathrm{Pu}$ by a different route than the floodplain crayfish, whether it was by filtration or by ${ }^{239} \mathrm{Pu}$ absorption from the digestive tract or the carapace. Although no proof exists for the tiltration mode of uptake in this study, it seems most likely that the ${ }^{239} \mathrm{Pu}$ in the soft tissues became associated at the gills. According to the data reported in Table 6 (p. 35), the soil at Site 1 had a ${ }^{239} \mathrm{Pu}$ concentration of about 1000 times greater than that of site 3 , and the ${ }^{239} \mathrm{Pu}$ concentration in soil at site 2 is slightly greater than that for Site 1. However, the whole body ${ }^{239} \mathrm{Pu}$ concentrations in crayfish from Site 1 and Site 2 are very similar; in both cases, the crayfish concentrations are slightly more than 100 times greater than the ${ }^{239} \mathrm{Pu}$ concentration in the crayfish at site 3 . With 
respect to ${ }^{239} \mathrm{Pu}$ concentrations, the soil on the floodplain surpasses the soil at the control area by three orders of magnitude, yet the crayfish at Site 1 and Site 2 are only two orders of magnitude greater than the crayfish at Site 3. Apparently, ${ }^{239} \mathrm{Pu}$ is taken up by the crayfish on the White Oak Creek floodplain, but biomagnification with respect to soil $\mathrm{Pu}$ is not evident.

Average ${ }^{239} \mathrm{Pu}$ concentrations in the soft tissues of crayfish from the three study areas are recorded in Table 7 (p. 37), and the values for the two floodplain areas are each compared to the control area. On the average, the soft tissues of crayfish from Site 1 and Site 2 had ${ }^{239} \mathrm{Pu}$ concentrations 44 to 95 times greater than the ${ }^{239} \mathrm{Pu}$ concentration in the soft tissues of crayfish from site 3 . The concentrations of ${ }^{239} \mathrm{Pu}$ in unfiltered water from the same study areas have similar ranges when compared. The filtered water samples have quite a different relationship; the concentration of ${ }^{239} \mathrm{Pu}$ in filtered water from Site 1 is only somewhat more than six times greater than the concentration of ${ }^{239} \mathrm{Pu}$ in filtered water from the control area. Since the range of ${ }^{239} \mathrm{Pu}$ concentrations in unfiltered water from either floodplain site is about two orders of magnitude greater than the ${ }^{239} \mathrm{Pu}$ concentration in unfiltered water from Site 3 , possibly some ${ }^{239} \mathrm{Pu}$ adsorbed to suspended solids or some redissolved ${ }^{239} \mathrm{Pu}$ from the sediments contribute ${ }^{239} \mathrm{Pu}$ to the soft tissues. It seems as if the unfiltered water more closely relates to the radionuclide concentration in the soft tissues, possibly due to not only soluble ${ }^{239} \mathrm{Pu}$ but also suspended solids contaminated with ${ }^{239} \mathrm{Pu}$ possibly touching the gills during filtration. Unfortunately, a determination of 
suspended solids was not included in the experimental design for the study.

Also in Table 7 (p. 37) are Bioaccumulation Factors based on the unfiltered or filtered water samples. Bioaccumulation Factors could serve as preliminary or indirect transfer coefficients in a model of radionuclide uptake; therefore, the soft tissues were related to the water with respect to ${ }^{239} \mathrm{Pu}$ concentrations. The Bioaccumulation Factors were calculated using the concentration of ${ }^{239} \mathrm{Pu}\left(\mathrm{dpm} \mathrm{g} \mathrm{g}^{-1}\right.$ dry wt.) as the numerator and the concentration of ${ }^{239} \mathrm{Pu}$ in either the unfiltered or the filtered water at each site $\left(\mathrm{dpm} \mathrm{ml}^{-1}\right)$ as the denominator. Bioaccumulation Factors are typically calculated with the basic assumption that the organism is in equilibrium with its aquatic environment. One limitation for Bioaccumulation Factors is they do not allow for the fact that organisms normally derive their nutrients from a variety of sources (Patzer, 1976). Since this basic assumption is violated because the crayfish ingest nonaquatic foods, the Bioaccumulation Factors in this study are useful mainly to compare the differences between the unfiltered and filtered water. For Site 1 and Site 2, the Bioaccumulation Factors for unfiltered water are one to two orders of magnitude less than those for filtered water. Since there was no detectable difference between the ${ }^{239} \mathrm{Pu}$ concentrations in the unfiltered and filtered water samples from Site 3 , the Bioaccumulation Factors are reported as the same inequality. According to Vanderploeg et al. (1975), Bioaccumulation Factors based on filtered water overpredict the concentration of the radionuclide in an organism. Since wet weights were not collected for the soft tissues, dry weights were 
used to calculate the Bioaccumulation Factors. Therefore, all the Bioaccumulation Factors are likely to be overestimated by a factor equal to a wet weight to dry weight ratio. Last7y, the greater Bioaccumulation Factor for the soft tissues of crayfish from Site 3 , based on the unfiltered water, compared to the corresponding values for the soft tissues of crayfish from Site 1 or Site 2, may be because Pu occurs in a somewhat more biologically available form at Site 3 or because the ${ }^{239} \mathrm{Pu}$ enters the crayfish from a nonaquatic pathway.

The distribution of ${ }^{239} \mathrm{Pu}$ (Table 5, p. 34) indicated that 21 to $33 \%$ of the body burden of ${ }^{239} \mathrm{Pu}$ was within or adsorbed to the digestive tract, which represents only 3 to $5 \%$ of the crayfish biomass. Soft tissues account for 11 to $13 \%$ of the biomass and have assimilated between 11 and $31 \%$ of the whole body burden. The carapace represented an average $84 \%$ of the biomass of an adult crayfish, and from 48 to $62 \%$ of the ${ }^{239} \mathrm{Pu}$ was associated with the carapace. Disregarding contaminated soil adhering to the external surface, a molted exoskeleton contains 0.3 to $3.3 \mathrm{dpm}{ }^{239} \mathrm{Pu}\left({ }^{239} \mathrm{Pu}\right.$ associated with the carapace $\mathrm{x}$ mass of the carapace). Contrasting the transfer of ${ }^{239} \mathrm{Pu}$ through the digestive tract as a frequently recurring means of dispersing some of the ingested isotope over an area of a few $\mathrm{m}^{2}$, the carapace molt, after progressively longer intermolt durations as the crayfish matures, deposits a relatively concentrated level of ${ }^{239} \mathrm{Pu}$ in a few $\mathrm{cm}^{2}$. Excretion and ecdys is could then be said to be equivalent but distinctive means by which a crayfish returns the isotope to its environment, at least temporarily. 


\section{Inventory of ${ }^{239} \mathrm{Pu}$ at Two}

Contaminated Sites

The total amount of ${ }^{239} \mathrm{Pu}$ present in the soil and the crayfish at Site 1 and Site 2 (Figure 2, p. 6) is referred to as an inventory. The ${ }^{239} \mathrm{Pu}$ inventory for crayfish can be compared with other components of the ecosystem that have been inventoried, as long as the size of the study sites is taken into account. The White 0ak Creek flondplain is two hundred times the size of either Site 1 or Site 2.

The plots on which the inventory is based have their surface dimensions as $100 \mathrm{~cm}$ by $100 \mathrm{~cm}$ with a depth of $20 \mathrm{~cm}$ in accordance with the format of a ${ }^{239} \mathrm{Pu}$ inventory for the White 0ak Creek floodplain (Auerbach et al., 1978). To calculate an inventory of soil Pu, the estimated mass of the soil is multiplied by an average concentration of ${ }^{239} \mathrm{Pu}$ in the crayfish chimneys at each site. Values for the inventory of soil Pu are reported in Table 8.

The 1977 estimated crayfish population density at Site 1 and Site 2 (Chapter II) multiplied by the average dry mass of trapped crayfish (Table B-2, Appendix B) from each site resulted in an approximate biomass of crayfish for each site. As with the soil, the crayfish biomass served as a multiplicand for the ${ }^{239} \mathrm{Pu}$ concentration in crayfish at Site 1 and Site 2 (Table 4, p. 32). Values for the inventory of ${ }^{239} \mathrm{Pu}$ in the crayfish from site 1 and Site 2 are included in Table 8 .

The ${ }^{239} \mathrm{Pu}$ in various biotic components relative to ${ }^{239} \mathrm{Pu}$ in soil have been expressed as inventory ratios (Auerbach et al., 1977). 
Table 8. Concentration of ${ }^{239} \mathrm{Pu}$, Concentration Ratios (CR) and the ${ }^{239} \mathrm{Pu}$ inventory of soil and crayfish from contamirated Sites 1 and 2 on the White Oak Creek floodplain in 1977

\begin{tabular}{|c|c|c|c|}
\hline & & - Site 1 & Site 2 \\
\hline \multirow[t]{2}{*}{ Soil ${ }^{a}$} & Concentration of ${ }^{239} \mathrm{Pu}\left(\mathrm{dpm} \mathrm{g}^{-1}\right)$ & $4.80 \times 10^{1}$ & $.1 .00 \times 10^{2}$ \\
\hline & Inventory ${ }^{b}$ of ${ }^{239} \mathrm{Pu}\left(\mathrm{dpm} \mathrm{m} \mathrm{m}^{-2}\right)$ & $1.25 \times 10^{7}$ & $2.60 \times 10^{7}$ \\
\hline \multirow[t]{4}{*}{ Crayfish } & Concentration of ${ }^{239} \mathrm{Pu}\left(\mathrm{dpm} \mathrm{g}^{-1}\right)$ & $7.28 \times 10^{-1}$ & $7.48 \times 10^{-1}$ \\
\hline & $C R^{C}$ & $1.52 \times 10^{-2}$ & $0.75 \times 10^{-2}$ \\
\hline & Average crayfish mass ${ }^{d}(g)$ & 2.96 & 2.88 \\
\hline & Estimated population density per $100 \mathrm{~m}^{2}$ & $44-55$ & $40-55$ \\
\hline & Inventory of ${ }^{239} \mathrm{Pu}\left(\mathrm{dpm} \mathrm{m} \mathrm{m}^{-\hat{\varepsilon}}\right)$ & $0.95-1.19$ & $0.86-1.18$ \\
\hline
\end{tabular}

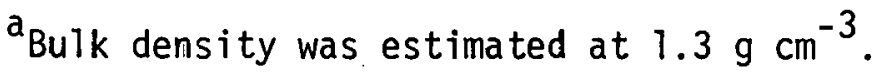

$b_{\text {Each }} \mathrm{m}^{2}$ had dimensions of $100 \mathrm{~cm} \times 100 \mathrm{~cm} \times 20 \mathrm{~cm}$.

${ }^{C} \mathrm{CR}=$ plutonium concentration in crayfish/plutonium concentration in soil.

${ }^{d}$ Oven $\left(65^{\circ} \mathrm{C}\right)$ dry weight. Wet (1ive) weight is about three times greater. 
An inventory ratio is calculated by dividing the inventory of ${ }^{239} \mathrm{Pu}$ in the crayfish ( $\mathrm{dpm} \mathrm{m}^{-2}$ ) by the inventory of ${ }^{239} \mathrm{Pu}$ in the soil $\left(\mathrm{dpm} \mathrm{m} \mathrm{m}^{-2}\right)$ at each site. For Site 1 crayfish the inventory ratio was about $8.6 \times 10^{-8}$. The inventory ratio for the crayfish living at Site 2 was about $3.9 \times 10^{-8}$. An inventory ratio of $10^{-8}$ is similar to that for tree leaves on the White Oak Creek floodplain (Auerbach et al., 1977). For soil fauna on the floodplain, the inventory ratio was about $10^{-7}$. An explanation for the lower inventory ratio in crayfish compared to that for the soil fauna in 1976 might be the smaller population of crayfish in 1977. If there were more crayfish biomass at each site with the same average mass and ${ }^{239} \mathrm{Pu}$ concentration, the inventory ratio would be similar to that for soil fauna. Another consideration is the dissimilarity in the unit areas on which the inventory ratios are based, Site 1 and Site 2 having an area over two orders of magnitude less than that of the floodplain.

Concentration Ratios (CR) of the crayfish in comparison with the soil based only on the ${ }^{239} \mathrm{Pu}$ concentration in both components of Site 1 and Site 2 are included in Table 8. The CR values for crayfish at these two sites indicate a minor movement of ${ }^{239} \mathrm{Pu}$ from the soil to the crayfish. The crayfish at these two sites have greater CR values than ground vegetation, lichens, and grasshoppers from the floodplain; the CR values for isopods and millipedes (Auerbach et al., 1978) surpass the $C R$ values of the crayfish from both study sites. All the $C R$ values here in range from $10^{-2}$ to $10^{-3}$. 


\section{Radiation Doses}

\section{Estimated Internal Dose to Crayfish}

The internal radiation dose to crayfish following ingestion of ${ }^{239} \mathrm{Pu}$ was estimated using analytical results (Table B-2, Appendix B). One assumption was that none of the Pu $\alpha$-radiation in the crayfish escaped through the exoskeleton. The dose to a clean carapace was calculated under the assumption that all the $\alpha$-radiation associated with it internally, plus any exterior contamination remaining after cleaning (Appendix B), was absorbed by the carapace. Data for the distribution of $\mathrm{Pu}$ throughout the muscles and organs were not available, but adult or subadult crayfish were assumed to be in equilibrium with $\mathrm{Pu}$ at the time they were trapped. Therefore, uniform Pu distribution was assumed for the soft tissues. For the digestive tract, uniform Pu distribution in its contents was assumed. Following the methodology compiled by Killough and Mckay (1976), the radiation dose to the wall of the digestive tract was assumed to be only $0.5 \%$ of the dose to its contents.

The basic equation for making a dose estimate to the animal exposed to the radiation is from Hine and Brownell (1956). The symbols are modified here for convenience:

Dose $=\frac{51.2 \mathrm{E}_{\alpha} \mathrm{q}}{\mathrm{m}}=\frac{\mathrm{rads}}{\mathrm{day}}$

where

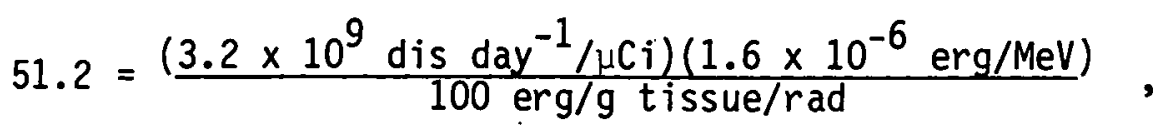




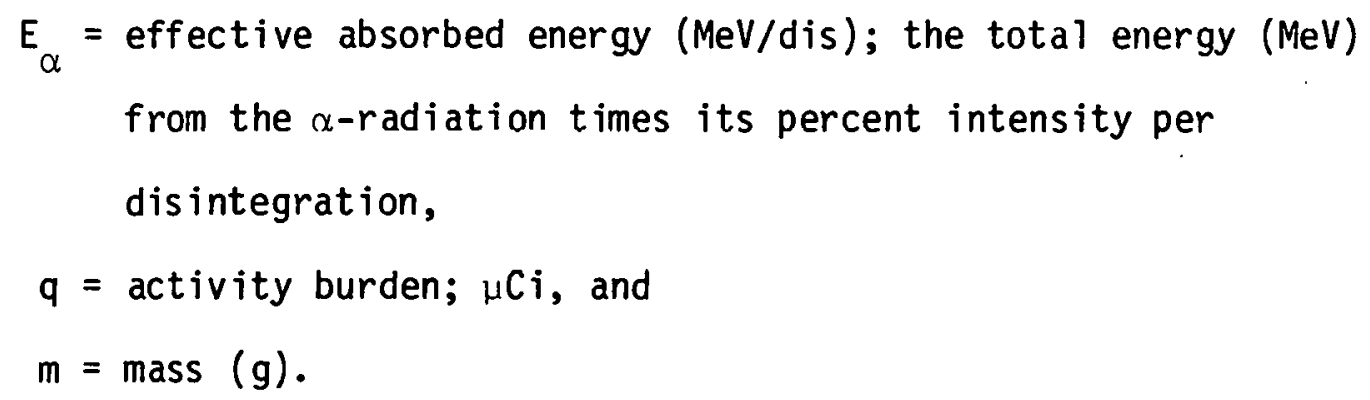

The effective absorbed energy $\left(E_{\alpha}\right)$ for ${ }^{239} \mathrm{Pu}$ is $5.143 \mathrm{MeV} \mathrm{dis}^{-1}$ (Kocher, 1977; Table C-1, Appendix C). Since all the analytical data (Table B-2, Appendix B) was calculated in terms of dpm's rather than Ci's, a conversion step was added to Eq. $3-5$, such that

Dose $=51.2 \times 5.143 \times \frac{1 \mu \mathrm{Ci}}{2.22 \times 10^{6} \mathrm{dpm}} \times \frac{\mathrm{dpm} 239 \mathrm{Pu}}{\mathrm{g}}=\frac{\mathrm{rads}}{\text { day }}$.

The estimated internal doses to various parts of the crayfish are reported in Table 9. Subsequent to calculating the internal dose to the digestive trace from its contents, the dose to the wall of the digestive tract was calculated.

Estimated Internal Dose to Man

In order to estimate an internal dose to man from ingestion of ${ }^{239} \mathrm{Pu}$-contaminated crayfish, the scenario used was that of a standard man (20 years of age) eating the soft tissues of ten crayfish from the White Oak Creek floodplain. The internal dose delivered to his entire body which would accrue during the fifty years subseqent to the ingestion of the contaminated crayfish is referred to as the "50-year dose commitment." Such a dose commitment as would result from a single intake of $1 \mu \mathrm{Ci}{ }^{239} \mathrm{Pu}$ via ingestion is referred to as a "dose 
Table 9. Estimated internal alpha radiation cose to crayfish body parts from ingestion of ${ }^{239} \mathrm{Pu}$. All subsets of analytical data (Table B-2, Appendix B) were used for summations.

\begin{tabular}{|c|c|c|c|c|}
\hline & $\begin{array}{c}\text { Digestive } \\
\text { tract }\end{array}$ & $\begin{array}{c}\text { Wall of } \\
\text { digestive } \\
\text { tract }^{\text {a }}\end{array}$ & $\begin{array}{l}\text { Soft } \\
\text { tissues }\end{array}$ & Carapace $^{b}$ \\
\hline${ }^{239} \mathrm{Pu}$ concentration $(\Sigma \mathrm{dpm})$ & 25.192 & $N A^{C}$ & 10.417 & 56.250 \\
\hline Total mass $(\mathrm{g})$ & 4.617 & $N A^{C}$ & 9.571 & 73.995 \\
\hline${ }^{239} \mathrm{Pu}\left(\mathrm{dpm} \mathrm{g}^{-1}\right)$ & 5.456 & $N A^{C}$ & 1.088 & 0.760 \\
\hline Estimated dose (rads day ${ }^{-1}$ ) & $6.47 \times 10^{-4}$ & $3.24 \times 10^{-6}$ & $1.29 \times 10^{-4}$ & $9.02 \times 10^{-5}$ \\
\hline Adjusted dose (mrads day $^{-1}$ ) & 0.647 & $3.24 \times 10^{-3}$ & 0.129 & $9.02 \times 10^{-2}$ \\
\hline
\end{tabular}

a Walls of the digestive tract were not analyzed separately. Dose was estimated as $0.5 \%$ of the dose to the digestive tract.

${ }^{b}$ Some exterior contamination may have been included.

CNot available. 
conversion factor." The 50-year total body dose conversion factor $\left(1.911 \times 10^{-2} \mathrm{rem}\right)$ for ingested ${ }^{239} \mathrm{Pu}(1 \mu \mathrm{C} i)$, reported by killough and Mckay (1976), was used to estimate the 50-year dose commitment for the scenario, such that

$\frac{1.911 \times 10^{-2} \mathrm{rem}}{\mu \mathrm{C} i \text { ingested }} \times \frac{1.088 \mathrm{dpm}}{\mathrm{g} \text { soft tissue }} \times 0.319 \mathrm{~g} \times \frac{1 \mu \mathrm{Ci}}{2.22 \times 10^{6} \mathrm{dpm}} \times$

10 soft tissues $\times \frac{1000 \mathrm{mrem}}{\text { rem }}=2.988 \times 10^{-5} \mathrm{mrem}$.

If the digestive tract were not removed before ingestion of the ten crayfish, the 50-year dose commitment would be increased:

$\frac{1.911 \times 10^{-2} \mathrm{rem}}{\mu \mathrm{Ci}{ }^{239} \mathrm{Pu} \text { ingested }} \times \frac{2.51 \mathrm{dpm}}{\mathrm{g}} \times 0.473 \mathrm{~g} \times \frac{1 \mu \mathrm{Cj}}{2.22 \times 10^{6} \mathrm{dpm}} \times$

10 crayfish $\times \frac{1000 \mathrm{mrem}}{\text { rem }}=1.022 \times 10^{-4} \mathrm{mrem}$.

The total body dose accrued from the ${ }^{239} \mathrm{Pu}$ during the 50 years following ingestion is only 0.00003 to $0.0001 \mathrm{mrem}$. Both values are several orders of magnitude lower than the radiation protection guides of the International Commission on Radiological Protection (1966) and the standards issued by the U.S. Environmental Protection Agency (1977) of 500 and $25 \mathrm{mrem} \mathrm{yr}^{-1}$ to the body, respectively. The dose commitment from other radionuclides in the White Oak Creek floodplain crayfish were not considered in these calculations, although their relative contribution would likely be appreciable. 
Estimated Annual Internal Dose to Two Types of Predators

Some of the potential predators for the ${ }^{239} \mathrm{Pu}$-contaminated crayfish from the White 0ak Creek floodplain include raccoons (Procyon lotor, $\sim 3.4 \mathrm{~kg}$ ), opossums (Didelphis marsupialis, $\sim 1.4 \mathrm{~kg}$ ), Southern screech owls (ㄴtus asio asio, $\sim 150 \mathrm{~g}$ ), Southern barred owls (Strix varia alleni, $740 \mathrm{~g}$ ), and red-shouldered hawks (Buteo lineatus, $\sim 1.1 \mathrm{~kg})$.

The annual total body dose to a predator that ate 100 Pu-contaminated crayfish was estimated. To estimate the dose, a 50-year dose commitment value for the total body of a standard man that ingested ${ }^{239} \mathrm{Pu}(1 \mu \mathrm{Ci})$ (Killough and McKay, 1976) was used as a basis from which the estimates could be derived. For the purpose of these calculations, the amount of time to digest a crayfish was assumed to be about the same for the predators mentioned and for a standard man. Time, as opposed to mass, is the more important parameter to adjust for alpha radiation doses. The 50-year dose conversion factor for the standard man was adjusted to an annual dose conversion factor for the predator, and a quality factor of 10 rads per $\alpha$-rem was used for an absorbed dose in the predator, such that

$\left(\frac{1.911 \times 10^{-2} \alpha-\text { rem }}{u C i{ }^{239} \mathrm{Pu} \text { ingested }} \times \frac{10 \mathrm{rads}}{\alpha-\text { rem }}\right) / 50$ years $=\frac{3.822 \times 10^{-3} \mathrm{rads}}{\mu \mathrm{Ci}^{239} \mathrm{Pu} \text { ingested }}$,

which estimates the annual total body dose for a predator per $\mu_{\mathrm{C}} \mathrm{C}$ ${ }^{239} \mathrm{Pu}$ ingested.

One type of predator, including the owls, ingests the entire crayfish. Later a pcllet of the indigestible portions might be disgorged. 
While the carapace is exposed to the strong stomach acids, ${ }^{239} \mathrm{Pu}$ is probably leached from it. The estimated total body dose to such a predator that ate $100 \mathrm{Pu}$-contaminated crayfish in their entirety (excluding a variable amount of external soil) is:

$\frac{3.822 \times 10^{-3} \mathrm{rads}}{\mu \mathrm{Ci}{ }^{239} \mathrm{Pu} \text { ingested }} \times \frac{1.042 \mathrm{dpm}}{\mathrm{g}} \times \frac{2.939 \mathrm{~g}}{\text { crayfish }} \times \frac{1 \mu \mathrm{Ci}}{2.22 \times 10^{6} \mathrm{dpm}} \times$ $\frac{100 \text { crayfish }}{\text { year }} \times \frac{1000 \mathrm{mrad}}{\mathrm{rad}}=5.267 \times 10^{-4} \mathrm{mrads}^{-1}$.

Another type of predator, such as the raccoon, supposedly strips the carapace from a crayfish before ingestion. The estimated annual dose to this type of predator after eating 100 Pu-contaminated crayfish without their carapaces (or associated Pu on the carapace surface) is:

$\frac{3.822 \times 10^{-3} \mathrm{rads}}{\mu \mathrm{Ci}{ }^{239} \mathrm{Pu} \text { ingested }} \times \frac{2.51 \mathrm{dpm}}{\mathrm{g}} \times 0.473 \mathrm{~g} \times \frac{1 \mu \mathrm{Ci}}{2.22 \times 10^{6} \mathrm{dpm}} \times$

$\frac{100 \text { crayfish }}{\text { year }} \times \frac{1000 \text { mirad }}{\text { rad }}=2.044 \times 10^{-4} \mathrm{mrads}^{-1}$.

The total body doses delivered by the ${ }^{239} \mathrm{Pu}$ to the predators, ranging between 0.0002 and 0.0005 mrads $\mathrm{yr}^{-1}$, are very low. Other radionuclides in the crayfish, as well as the possibility of the predator ingesting other contaminated foods, would of course contribute a greater dose. 
CHAPTER IV

UPTAKE OF ${ }^{237} \mathrm{PU}$ BY CRAYFISH

IN THE LABORATORY

As laboratory research tool for studies of Pu kinetics, ${ }^{237} \mathrm{Pu}$ is more versatile than ${ }^{239} \mathrm{Pu}$ (IV). Direct detection of ${ }^{237} \mathrm{Pu}$ photons in live organisms is possible; therefore, destructive sampling is avoided, and whole organisms can be repeatedly counted in an uptake experiment. Since ${ }^{237} \mathrm{Pu}$ has negligible alpha activity, special containment facilities are unnecessary. The specific activity of ${ }^{237} \mathrm{Pu}$ (Table $\mathrm{C}-1$, Appendix $\mathrm{C}$ ) is about six orders of magnitude greater than that for ${ }^{239} \mathrm{Pu}$, so reasonably high ( $\mu \mathrm{Ci}$ to $\mathrm{nC} i$ ) levels of ${ }^{237} \mathrm{Pu}$ approach actua ${ }^{239} \mathrm{Pu}$ ( $p C i$ ) concentrations (per unit of mass) on the White 0ak Creek floodplain. One restraint is that the ${ }^{237} \mathrm{Pu}$ isotope has a limited availability because it is prepared only when economically reasonable (usually in a $20 \mu \mathrm{Ci}$ batch).

In a laboratory experiment, ${ }^{237} \mathrm{Pu}$ was used to determine the rate of Pu uptake by crayfish. Uncontaminated crayfish were fed a series of fish spiked with ${ }^{237} \mathrm{Pu}$. Uptake of the isotope by the crayfish was monitored over the chronic feeding study.

\section{Materials and Methods}

\section{Experimental Facility}

The uptake study was conducted in a controlled environment chamber. Incandescent light was on $8 \mathrm{hr}$ and off $16 \mathrm{hr}$ each day. Temperatures in the chamber fluctuated between $15^{\circ}$ and $18^{\circ} \mathrm{C}$. Air supply to the chamber 
was directed into water through air-breaking stones for crayfish or fish.

\section{Crayfish}

Eight uncontaminated crayfish were brought to the environmental chamber from the control stream; average live mass of the crayfish was $8.9 \mathrm{~g}$. Each was placed in a plastic box containing spring water. Boxes were tipped to create a variable water depth $(0.5$ to $3 \mathrm{~cm})$. Air circulated continuously in the deeper water. Spring water was changed daily. Each box contained gravel and a strip of plastic mesh $(7 \times 14 \mathrm{~cm})$ curved to provide a climbing surface and a light shelter underneath. Crayfish were fed either a spiked minnow or bluegill or processed alfalfa pellets.

Fish

Minnows or bluegill received $50 \lambda\left(1.95 \times 10^{4} \mathrm{dpm}\right)$ of ${ }^{23 /} \mathrm{Pu}$ citrate solution by intraperitioneal injection. Fish were allowed to equilibrate 24 to $48 \mathrm{hr}$ in buckets containing 1.5 liters of spring water and air. Average masses of minnows and bluegill were 1.5 and $2.0 \mathrm{~g}$ respectively. As fish were needed to feed crayfish, or as the fish died, they were counted for ${ }^{237} \mathrm{Pu}$ activity in plastic dishes like the standard. Fish not needed immediately after a $48 \mathrm{hr}$ equilibration period were temporarily frozen.

\section{Gamma Detection Equipment}

Crayfish, minnows, and bluegill were analyzed by gamma spectrometry with a Packard Multi-Channel Analyzer in conjunction with a flat crystal $\left[\mathrm{NaI}(\mathrm{Tl}), 3 \times 3^{\prime \prime}\right]$. Efficiency of the equipment was $18 \%$. 


\section{$\underline{\text { Standard }}$}

A flat ${ }^{237} \mathrm{Pu}$ standard was prepared using a strip of ordinary sponge to represent either a crayfish or a fish body. The sponge was centered in a plastic dish $(7 \mathrm{~cm} \mathrm{diam})$ and a $50 \lambda$ volume $\left(1.95 \times 10^{4}\right.$ $\mathrm{dpm}$ ) of ${ }^{237} \mathrm{Pu}$ citrate was dabbled from end to end. After drying for an hour, the standard was sealed with a plastic cover and taped. The spiked sponge was always oriented facing the crystal on its North-South axis.

\section{Sample Geometry}

Crayfish to be counted were placed in clean plastic dishes. The body and chelae were outstretched and the telson and uropods were tucked. Crayfish were immobilized with moist tissues and a plastic cover on the dish. Minnows and bluegill were similarly confined while lying on one side.

\section{Feeding Periods}

Either a spiked minnow or bluegill was fed to a crayfish once each week. Before and after each feeding, measurements of ${ }^{237} \mathrm{Pu}$ activity were made for the $f$ ish and the crayfish. Each feeding period lasted approximately a day, and the amount of ${ }^{237} \mathrm{Pu}$ possibly ingested by the crayfish was taken to be the difference in the amount of the isotope in the fish before and after it was given to the crayfish. The amount thus calculated was probably not wholly ingested due to ${ }^{237} \mathrm{Pu}$ in the water, on the gravel, or on the surface of the container. In no feeding period was an entire minnow or bluegill consumed by a crayfish. 
Isotope

Details about the production and physical characteristics of ${ }^{237} \mathrm{Pu}$, its dilution into sodium citrate, and information about other isotopes discussed in this investigation are compiled in Appendix $C$.

\section{Results}

Biological Uptake of $237 \mathrm{Pu}$ by Crayfish

After the first feeding, an average $72.4 \%$ of the amount of ${ }^{237} \mathrm{Pu}$ estimated to have been consumed was excreted by the crayfigh after the second day. All the crayfish probably had not voided their digestive tracts at the time they were counted for ${ }^{237} \mathrm{Pu}$ activity after the first or subsequent feeding periods. The crayfish did not eat for four to six days before death (due to faulty laboratory apparatus). In no case did equilibrium seem to be in prospect. A true equilibrium obviously would have been reached only after an extended period of time with the week ly feedings.

Overall uptake, the amount of ${ }^{237} \mathrm{Pu}$ detectable at death divided by the total amount of ${ }^{237} \mathrm{Pu}$ estimated to have been consumed over the course of the experiment (27 th 37 days per crayfish), averaged $3.5 \%$. The lowest uptake by a single crayfish was $1.4 \%$ of the available ${ }^{237} \mathrm{Pu}$ in its food. Approximately $13 \mathrm{nCj}{ }^{237} \mathrm{Pu}$ were available to each crayfish during this study.

Body burdens of ${ }^{237} \mathrm{Pu}$ in uncontaminated crayfish feeding on spiked ininnows or bluegill are shown in figure 6 . The exponential curve through the data, 


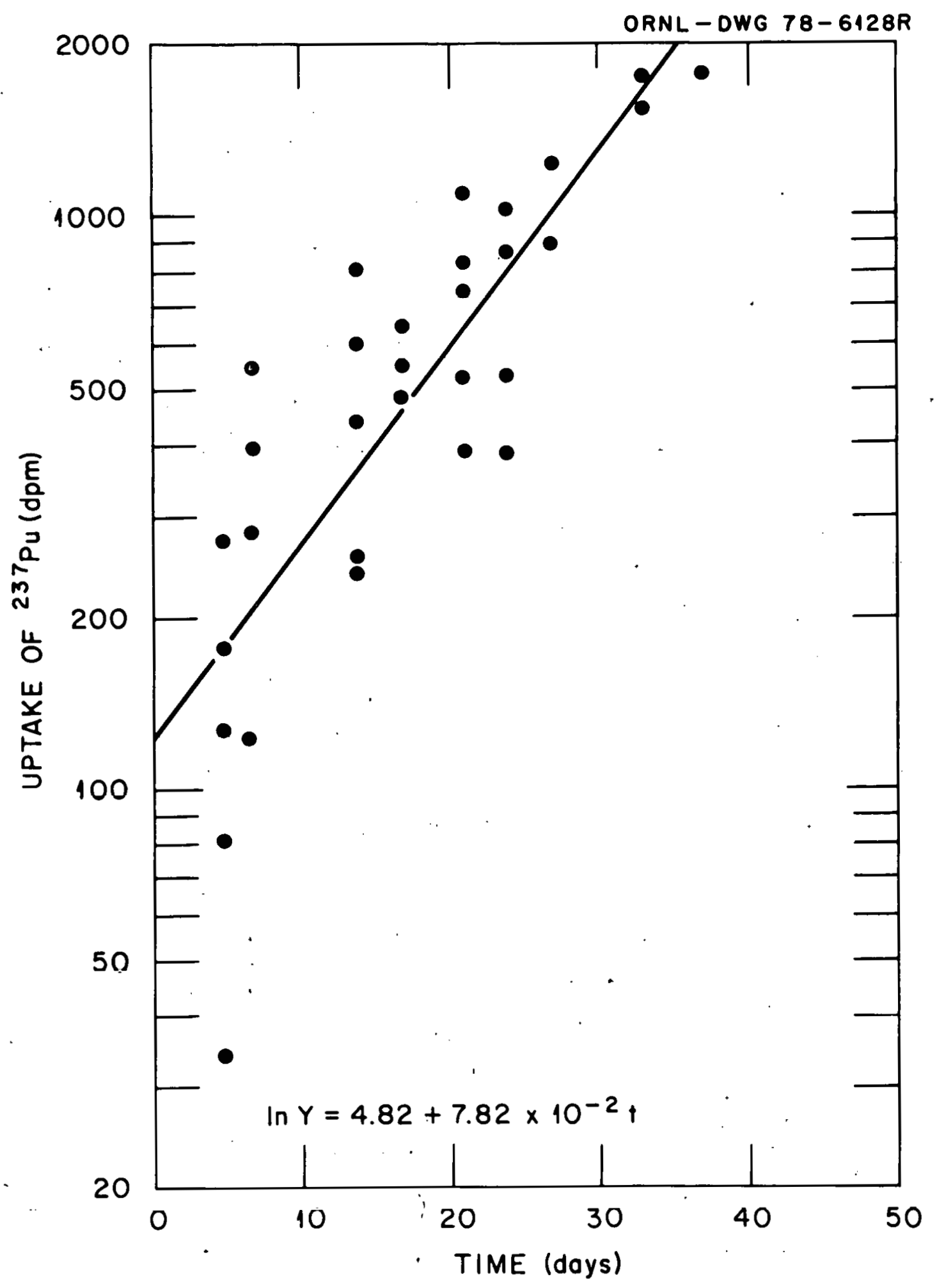

. Figure 6. Uptake of ${ }^{237} \mathrm{Pu}(\mathrm{dpm})$ vs. time (days). 
In $Y=4.82+7.82 \times 10^{-2} t$

had a coefficient of determination $\left(r^{2}\right)$ of 0.69 .

Distribution of ${ }^{237} P_{u}$ in Laboratory Crayfish at Death

Individual crayfish were dissected after death into carapace and soft tissues (including the digestive tract). For all the crayfish fed spiked fish, up to $93 \%$ of the total body burden was detected in the body tissues. From 7 to $21 \%$ was associated with the carapace. Of three crayfish that had not fed on spiked fish for six days before death, from 18 to $37 \%$ of the ${ }^{237} \mathrm{Pu}$ was associated with the carapace. Complementary data for the digestive tract with its contents and the soft tissues ranged from 63 to $82 \%$ of the whole body burden at death.

$$
\text { Absorption and Adsorption of } 237 \mathrm{Pu}
$$

From the graph (Figure 6) a rate at which uptake of ${ }^{237} \mathrm{Pu}$ occurred was calculated. The uptake rate of ${ }^{237} \mathrm{Pu}$ by crayfish should be able to be transferred directly to a model of ${ }^{239} \mathrm{Pu}$ uptake by crayfish. However, this value for uptake rate $\left(0.0782 \mathrm{day}^{-1}\right)$ is applicable only for about the first 40 days of a chronic feeding experiment in which crayfish ingest $\mathrm{Pu}$ until the uptake and elimination of the radionuclide equilibrate.

The value for the amount of ${ }^{237} \mathrm{Pu}$ retained by the crayfish after the initial feeding period in this study might appear to be an overestimation, since $99 \%$ or more of the Pu fed to the crayfish would be expected to pass through the digestive tract unassimilated. According to Reichle et al. (1970) absorption of actinide elements (including Pu) 
through the wall of the digestive tract is much lower $(<1 \%)$ than the data ( $>25 \%$ ) in this study showed. In this laboratory experiment, the sodium citrate form of the ${ }^{237} \mathrm{Pu}$ (Appendix $\mathrm{C}$ ) was chosen to permit ${ }^{237} \mathrm{Pu}$ penetration of the membranes of the digestive tract. Obviously, the chelating agent enhanced absorption of ${ }^{237} \mathrm{Pu}$ by the crayfish during the first feeding period. In the field, saprovore assimilation of radionuclides from detritus was lowest since soluble forms had been leached and the remaining were in poorly digestible tissue structures (Reichle et al., 1970). The amount of ${ }^{237} \mathrm{Pu}$ consumed in this study (by taking a ratio of the activity remaining in the fish after it was fed to the crayfish to the activity in the fish before the feeding period) did not incorporate an estimate of the amount of ${ }^{237} \mathrm{Pu}$ possibly adsorbed to rocks or to the plastic container. Additionally, some adsorption of ${ }^{237} \mathrm{Pu}$ to the exterior crayfish carapace was probably occurring from the shredded fish and from the excrement in the water in the plastic container.

The distribution of ${ }^{237} \mathrm{Pu}$ in laboratory crayfish differs from the distribution of ${ }^{239} \mathrm{Pu}$ in floodplain crayfish (Table 5, p. 34). Less than $37 \%$ of the ${ }^{237} \mathrm{Pu}$ was associated with the carapaces of laboratory crayfish at death, but up to $62 \%$ of the ${ }^{239} \mathrm{Pu}$ was associated with the carapaces of floodplain crayfish. The adult crayfish at Site 1 and Site 2 (Figure 2, p. 6) were probably maintaining an equilibrium with their environment, whereas the laboratory crayfish were not at equilibrium at any time in the experiment. Some ${ }^{237} \mathrm{Pu}$ could possibly have adsorbed to the exterior carapaces of the experimental crayfish, but whether the amount of ${ }^{237} \mathrm{Pu}$ adsorbed by the carapaces 
of the laboratory crayfish approximates the quantity of ${ }^{239} \mathrm{Pu}$ adsorbed to the carapaces of floodplain crayfish is unknown.

Equilibrium was never attained during the time the crayfish could be kept alive in the laboratory not only because assimilation of $\mathrm{Pu}$ across the digestive tract is so low, but also because ${ }^{237} \mathrm{Pu}$ does not follow simple kinetics. Even with chelation, the average overall ${ }^{237} \mathrm{Pu}$ uptake was estimated at on $1 y 3.5 \%$. An alternative method for calculating an assimilation estimate and an equilibrium Pu activity per gram of crayfish needed for the model of ${ }^{239} \mathrm{Pu}$ in crayfish would have been to do an acute study in which elimination was monitored after an initial high dose of ${ }^{237} \mathrm{Pu}$. A value for an elimination coefficient could have been calculated using,

$Y(t)=Y_{0} e^{-k t}$

where

$$
\begin{aligned}
Y(t) & =\text { body burden at time } t, \\
Y_{0} & \equiv \text { Inftía ì vàlue ot body burden, } \\
e & =\text { base of the natural logarithm, and } \\
k & =\text { elimination coefficient. }
\end{aligned}
$$

A weighted elimination coefficient could have been obtained from the multiple component retention curve likely to have been generated by first calculating for each component the product of its biological half-life times the proportion of total activity lost in that component and subsequently using the sum of those products as the divisor for the radioactive decay constant, 0.693 , in accordance with the isotopic principles utilized by Reichle (1967). 


\section{CHAPTER V}

\section{DISCUSSION}

\section{Comparison of Radionuclide Distributions in Three \\ Species of Contaminated Crayfish in the \\ Vicinity of White Oak Creek}

The proportion of ${ }^{239} \mathrm{Pu}$ in the carapaces of $\underline{\mathrm{c}}$. carolinus, which ranges between 55 and $62 \%$ of the body burden (Table $5, p .34$ ) is higher in essentially all cases than the proportions of other radionuclides in carapaces of other crayfish in the vicinity of White Oak Creek.

Cambarus bartonii and Cambarus longulus from White 0ak Creek were analyzed for the radioisotopes of cobalt, cesium, and ruthenium by Tanner (1964). The percentage of the radioactive body burden in the carapace ranged from 46 to $51 \%$ for ${ }^{60} \mathrm{Co}, 45$ to $46 \%$ for ${ }^{137} \mathrm{Cs}$, and 51 to $52 \%$ for ${ }^{106} \mathrm{Ru}$.

For the soft tissues, the proportions were strikingly variable. In C. carolinus, 11 to $12 \%$ of the ${ }^{239} \mathrm{Pu}$ body burden was found in the soft tissues. In C. bartonii and C. lnngulus about $10 \%$ of the ${ }^{60} \mathrm{Co}$, 39 to $42 \%$ of the ${ }^{137} \mathrm{Cs}$, and only about $5 \%$ of the ${ }^{106} \mathrm{Ru}$ body burden was found in the soft tissues.

The proportion of ${ }^{239} \mathrm{Pu}$ in the digestive tracts of $\underline{\mathrm{c}}$. carolinus ranged from 26 to $32 \%$ of the total burden. Between 38 and $44 \%$ of the ${ }^{60} \mathrm{Co}, 12$ to $16 \%$ of the ${ }^{137} \mathrm{Cs}$, and about $43 \%$ of the ${ }^{106} \mathrm{Ru}$ was in the digestive tracts of $\underline{c}$. bartonij and $\underline{c}$. longulus. Of the crayfish in both studies, the digestive tract fractions were analyzed with their contenls iricluded. 
Of the radionuclides included in these studies, the distribution of ${ }^{239} \mathrm{Pu}$ appears to be similar to ${ }^{60} \mathrm{Co}$. Among the radionuclides for which data for the distribution throughout the crayfish body are available, ${ }^{137}$ Cs seems to be the most distinctive. Whereas ${ }^{137} \mathrm{Cs}$ is associated with the soft tissues, ${ }^{60} \mathrm{Co},{ }^{106} \mathrm{Ru}$, and ${ }^{239} \mathrm{Pu}$ are predominantly distributed in the digestive tracts and the carapaces.

\section{Comparison of ${ }^{239} \mathrm{Pu}$ Concentrations in \\ Crayfish and Other Biota of the White Oak Creek Floodplain}

Sampled leaf litter (Auerbach et al., 1978) from the White Oak Creek floodplain had about twenty times more $\mathrm{Pu}$ (on a per gram basis) than the crayfish in this investigation. According to Table 6 (p. 35) contaminated floodplain crayfish had between 0.73 and $0.75 \mathrm{dpm} \mathrm{Pu} \mathrm{g}^{-1}$. Of the sampled floodplain fauna that also contact soil to some extent, isopods and millipedes had whole body concentrations of Pu between eight and eleven times greater than crayfish. Crayfish had twice the Pu concentration of grasshoppers and about twelve times more $\mathrm{Pu}$ (on a per gram basis) than a median value of shrew carcasses (Auerbach et al., 1978). In explanation, grasshoppers and shrews have considerably less association with the contaminated soil than the aforementioned ecosystem components that quite likely are externally contaminated.

After 30 years residence in the floodplain soil then, $\mathrm{Pu}$ has demonstrated very low transfers to biota. The prevalent oxidation state of $\mathrm{Pu}$ on the floodplain is $\mathrm{Pu}$ (IV). Because of hydrolysis, $\mathrm{Pu}$ (IV) is readily and irreversibly sorbed to the soil. The more soluble species 
Pu(VI) hypothetically dominates plant availability; however, Bondietti et al. (1976)-have shown that $\mathrm{Pu}(\mathrm{VI})$ is relatively unstable. In the presence of naturally occurring organic substances, $\mathrm{Pu}(\mathrm{VI})$ is reduced to $\mathrm{Pu}(\mathrm{IV})$. If $\mathrm{Pu}(\mathrm{VI})$ were available to plants, it would probably not persist at that oxidation state due to the biochemical environment (Delaney and Francis, 1978).

\section{Biochemical Transfer of $239 \mathrm{Pu}$ at Ecdys is}

Chitin ( $\alpha$ type) is a widely recognized molecular constituent of crustacean cuticles (Dennell, 1960), and it is essentially a polysaccharide. Calcium carbonate, another well-known constituent of the crustacean cuticle, occurs mainly as calcite. A third cuticular component is the protein, some of which has been identified as sclerotin (Stevenson, 1969).

The catabolic activities of the integumentary tissues during premolt are known to result in calcium resorption from the old exoskelton (Skinner, 1962). Constituents from the old exoskeleton are probably stored in the blood, the hepatopancreas, or the gastroliths. Whereas glycogen is accumulated in the blood, proteins and lipids are known to be transported to the hepatopancreas for storage (Passano, 1960). Gastroliths are $\mathrm{CaCO}_{3}$ concretions in the proventriculus (stomach) that form during the premolt stages (Bliss, 1968). The gastroliths of Gecarcinus lateralis disappear with in three days after ecdys is (Skinner, 1962).

Experiments with ${ }^{14} \mathrm{C}$-acetylglucosamine have indicated that substantial amounts of the absorbed constituents (chitin) of the old 
cuticle are used to manufacture the new cuticle (Gwinn and Stevenson, 1973). An increase in chitin synthesis has been noted in premolt (Stevenson, 1974). It seems that the mineral components of the gastroliths are used subsequently to harden the new exoskeleton. According to Guary et al. (1976), an appreciable fixation of Pu takes place in the hepatopancreas of Cancer pagurus during intermolt. Females fixed three times more $\mathrm{Pu}$ than the males. He suggests the phenomenon might be related to the biochemical transfers during a molt. An observation made by Ward (1966) with respect to the lobster Homarus vulgaris was that the ${ }^{239} \mathrm{Pu}$ content of the cast she 11 was about two times the ${ }^{239} \mathrm{Pu}$ concentration of an intermolt lobster. In conjunction, the soft tissues (including the hepatopancreas) contained relatively less ${ }^{239} \mathrm{Pu}$ after ecdysis. Ward did not report the sex of the molted lobster.

If a similar phenomenon occurs in $\underline{\mathrm{C}}$. carolinus, one possible way of accounting for the drain of ${ }^{239} \mathrm{Pu}$ from the hepatopancreas and the simultaneous doubling of ${ }^{239} \mathrm{Pu}$ in the exoskelton might be the production of some enzyme by the hepatopancreas at the time of apolysis (separation of the epidermis from the cuticle). Obvinusly ${ }^{239} p_{14}$ would have to be located at a non-functional position in the enzyme. The transfer of ${ }^{239} \mathrm{Pu}$ to the innermost layer of the cuticle would depend on its affinity for the nuclide.

No data for Pu distribution at ecdysis in $\underline{\mathrm{C}}$. carolinus were available from this investigation. Therefore, the consideration of a change in Pu distribution in these crayfish has been admittedly speculative. The phenomenon seemed plausible, however, and its consideration served 
the purpose of revealing the more important parameters to be measured in a subsequent study.

$$
\begin{aligned}
& \text { Revisions in the Model of } \\
& { }^{239} \mathrm{Pu} \text { in Crayfish }
\end{aligned}
$$

The graphic compartmental model of ${ }^{239} \mathrm{Pu}$ in crayfish presented in Figure 3 (p. 31) has been referred to in several places. In Chapter I a discussion of $\mathrm{Pu}$ in soft tissues and the digestive tract was presented. The possible ingestion of the carapace by a predator was also mentioned. The three compartments internal to the crayfish in the model were used in the analysis of ${ }^{239} \mathrm{Pu}$ concentrations in the crayfish body parts (Chapter III). Similarly, the distribution of ${ }^{239} \mathrm{Pu}$ was compared on the basis of those body parts. Because the transfers of ${ }^{239} \mathrm{Pu}$ from compartments external to the crayfish to those internal to the crayfish had not been evaluated, one of the transfers (from food to the digestive tract) was studied in Chapter IV.

The model, without being challenged as successful, could stand to be amended while its simplicity is maintained. In Figure 7 , the carapace was subdivided into two compartments to represent contamination from either ingestion (and subsequent assimilation) or transfer of soil $\mathrm{Pu}$ to the exterior carapace. The carapace surface is contaminated by $\mathrm{Pu}$ in the soil during burrowing because $\mathrm{Pu}$ from soil particles adsorbs to the punctations of the carapace surface. The amount of Pu assimilated through the digestive tract and soft tissues to the carapace internally is probably surpassed by the amount of Pu adsorbed to the exterior carapace. Exterior contamination of the carapace surface is 


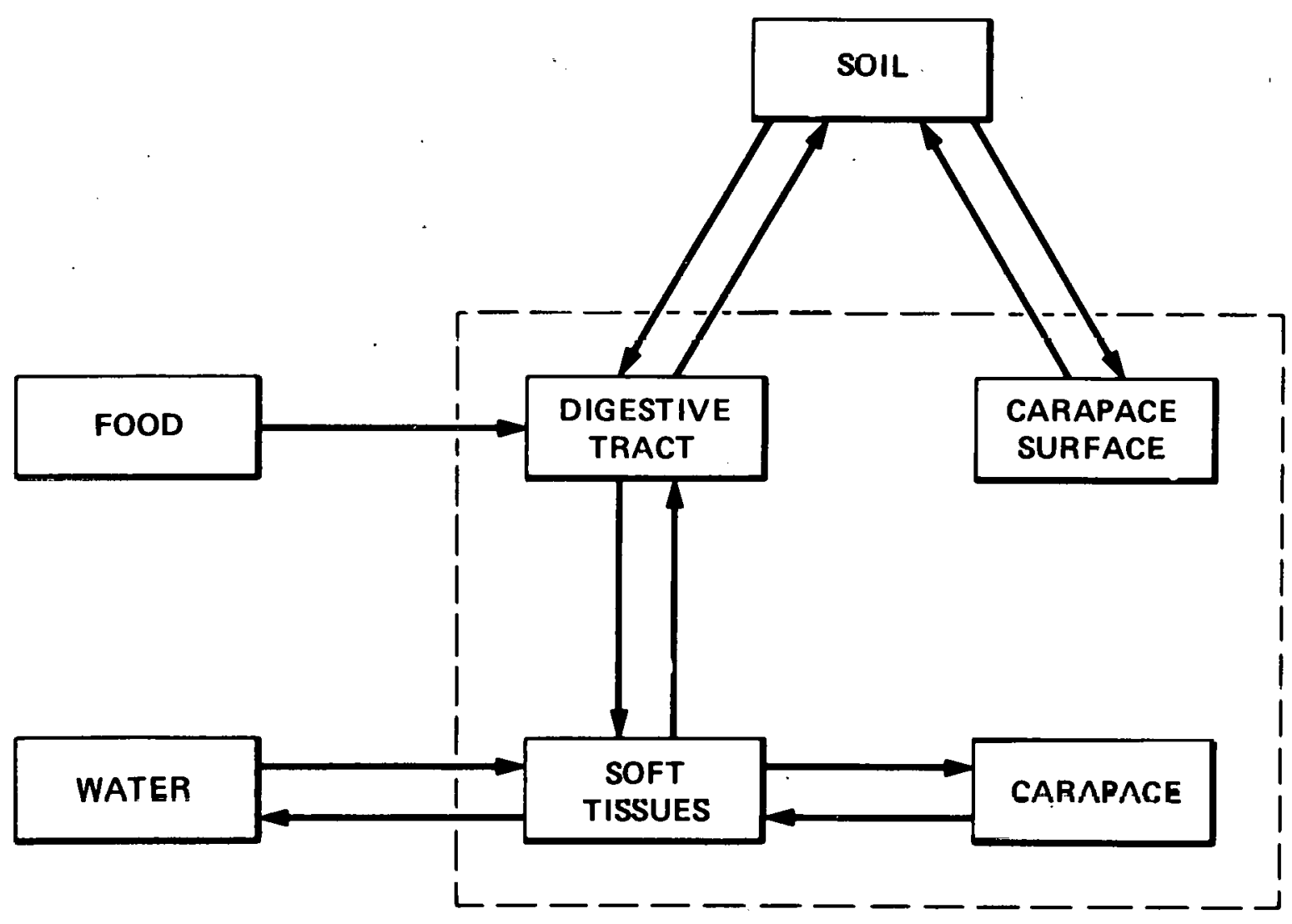

Figure 7. Graphic compartmental model of Pu movement through a crayfish indicating the interaction of soil with the carapace surface. The four components of the crayfish are enclosed hy the hroken lines. 
probably directly proportional to the surface area of the carapace, the number of punctations, and the presence of water as a means for portage. Interior contamination of the carapace results from assimilation of $\mathrm{Pu}$ to the carapace from the soft tissues. To some extent $\mathrm{Pu}$ assimilated into the carapace is returned to the soft tissues (possibly the hepatopancreas) until ecdysis.

Figure 8 is a representation of Pu during postmolt in a crayfish. From the studies by Guary et al. (1976) and Ward (1966), it is known that a rapid transfer of ${ }^{239} \mathrm{Pu}$ from the soft tissues to the carapace occurs during premolt. After ecdysis, if the supply of calcium in the gastroliths is insufficient for fortification of the new exoskeleton, the crayfish ingests the shed carapace. The shed carapace is apt to have metabolized about double the concentration of ${ }^{239} \mathrm{Pu}$ of the intermolt carapace. Additionally, the shed carapace has ${ }^{239} \mathrm{Pu}$ adsorbed to any encrusted soil on its surface. The arrows from the carapace and the carapace surface to the digestive tract represent the ingestion. If the molted exoskeleton is ingested, part of the ${ }^{239} \mathrm{Pu}$ associated with it is excreted and part of it is essentially recycled to the carapace, thereby rendering it unavailable except to those predators that ingest the whole crayfish.

Information about ${ }^{239} \mathrm{Pu}$ was not available for crayfish and their sources of contamination other than for the seven compartments used. Compartments such as flora, fauna, and soil water were disregarded due to their insignificance in comparison with more contaminated and more often contacted sources. Other compartments (e.g., fallout, ambient air, and resuspended soil), which were inappropriate for similar reasons, were disregarded also. 


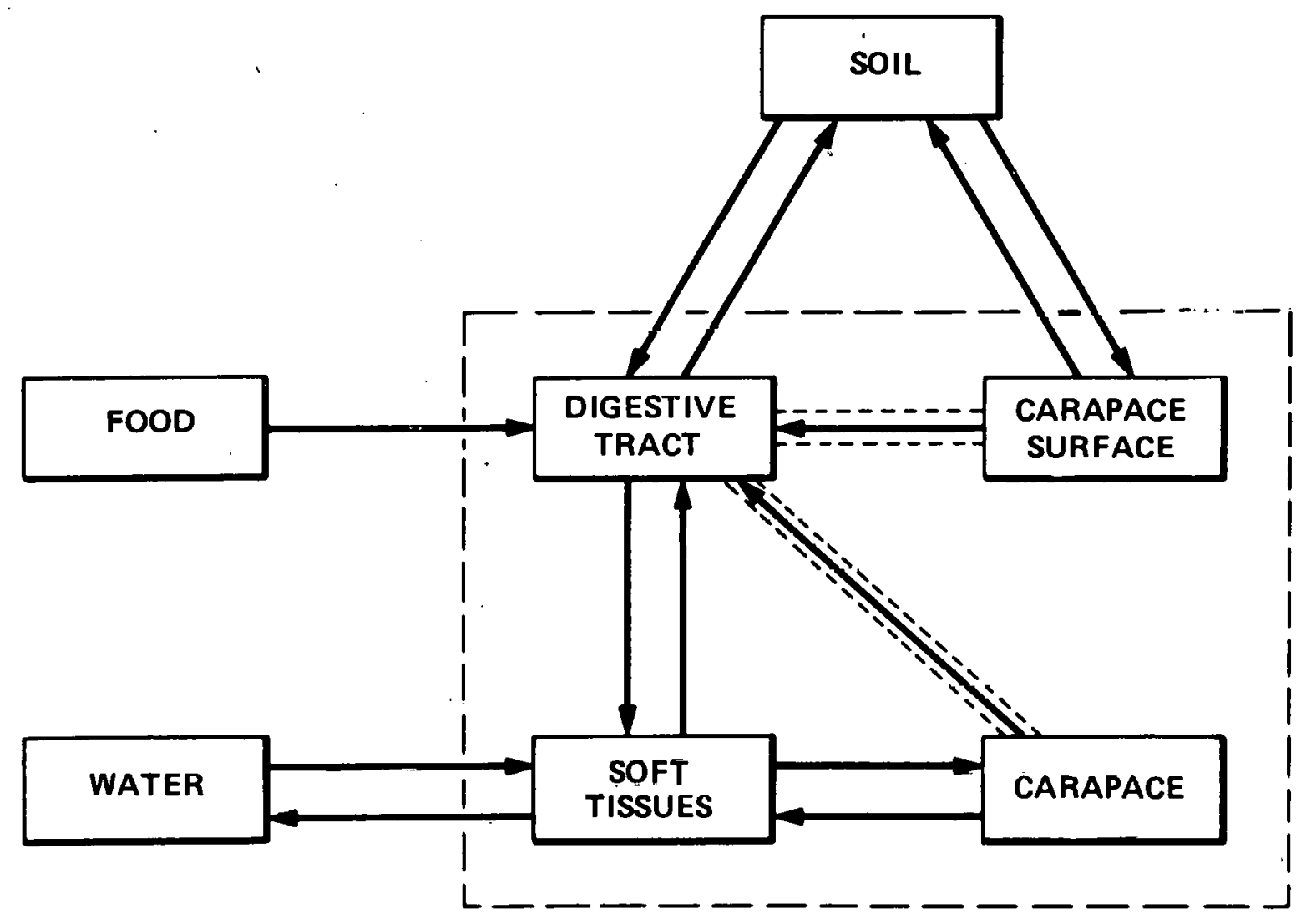

Figure 8. Graphic compartmental model of $\mathrm{Pu}$ movement through a crayfish emphasizing the transfer of $\mathrm{Pu}$ from the carapace surface and the carapace to the digestive tract after ecdysis. 


\section{SUMMARY AND CONCLUSIONS}

The number of contaminated crayfish at two sites on the White 0ak Creek floodplain was estimated. Chimney count data and results from a burrow cast indicate that from 44 to 55 crayfish existed at site 1 in 1977. Similarly, 40 to 55 adult or subadult crayfish were active at Site 2 in 1977. The density of chimneys $\mathrm{m}^{-2}$ was greatest in the first meter from a stream bank. The crayfish population at both sites. decreased from 1976 to 1977.

Average ${ }^{239} \mathrm{Pu}$ concentrations in contaminated crayfish were more than one hundred times greater than control crayfish. With respect to ${ }^{239} \mathrm{Pu}$ concentrations, however, the floodplain soil surpassed background level soil by three orders of magnitude. Crayfish concentration. differences might be due either to some chemical differences with respect to $\mathrm{Pu}$ or to a functional ecosystem variation among the sites. The average ${ }^{239} \mathrm{Pu}$ concentration in the digestive tracts of contaminated crayfish was six to eight times greater than that in their soft tissues and eight to fifteen times greater than that in their carapaces (on a per gram basis). The concentration of ${ }^{239} \mathrm{Pu}$ in unfiltered water seems to relate to that in the soft tissues.

From 48 to $62 \%$ of the ${ }^{239} \mathrm{Pu}$ body burden was associated with the carapace, which represented about $84 \%$ of the biomass of an adult crayfish. The digestive tracts constituted $5 \%$ of the biomass; nevertheless, 21 to $33 \%$ of the body burden was within or adsorbed to them. The 
proportion in the soft tissues ranged from 11 to $31 \%$ of the body burden, and soft tissues accounted for 11 to $13 \%$ of the biomass.

For crayfish ingesting contaminated food, an uptake rate for $\mathrm{Pu}$ was calculated using ${ }^{237} \mathrm{Pu}$ in sodium citrate. The uptake rate is based on the first 40 days of a chronic feeding experiment. A steady-state between uptake and elimination of ${ }^{237} \mathrm{Pu}$ was not attained in that time. From 63 to $82 \%$ of the body burden was associated with the digestive tract and soft tissues, and less than $37 \%$ of the ${ }^{237} \mathrm{Pu}$ was associated with the carapace. Whether the amount of ${ }^{237} \mathrm{Pu}$ adsorbed to the carapace surface approximated the quantity of ${ }^{239} \mathrm{Pu}$ adsorbed to that of floodplain crayfish was not determined.

The ${ }^{239} \mathrm{Pu}$ inventory of crayfish at two sites on the floodplain was calculated by multiplying the estimated biomass of the crayfish by their average ${ }^{239} \mathrm{Pu}$ concentration. The proportion of ${ }^{239} \mathrm{Pu}$ to which the burrowing crayfish were exposed and estimated to be bound by them was calculated by dividing the ${ }^{239} \mathrm{Pu}$ inventory in crayfish by the ${ }^{239} \mathrm{Pu}$ inventory in soil for each site. An inventory ratio was evaluated as somewhat greater than $10^{-8}$.

An estimation of the internal radiation dose to a crayfish due to ingested ${ }^{239} \mathrm{Pu}$ was calculated as slightly more than $0.2 \mathrm{mrads} \mathrm{day}^{-1}$ to the wall of its digestive tract, its soft tissues, and its metabolizing carapace. Radiation dose estimates for potential predators of contamtnated crayfish were also evaluated. Less than $3 \times 10^{-5}$ mrem would accrue over 50 years of life in a standard man if he were to ingest the soft tissues of ten contaminated crayfish from the floodplain. 
Appendixes include the (a) specifications for a crayfish trap designed for this study, (b) methodology for analytical determination of Pu in body parts of crayfish, (c) characteristics of Pu isotopes, and (d) definitions for some of the terminology used throughout the study.

From this investigation of the burrowing crayfish from the White Oak Creek floodplain, the following conclusions seem reasonable:

1. Contaminated crayfish from the floodplain have ${ }^{239} \mathrm{Pu}$ concentrations slightly more than two orders of magnitude greater than those for control crayfish, even though the soil on the floodplain has a ${ }^{239} \mathrm{Pu}$ concentration three orders of magnitude. greater than that of background soil. Therefore, biomagnification with respect to soil $\mathrm{Pu}$ is not a concern.

2. The greatest proportion of ${ }^{239} \mathrm{Pu}$ in a crayfish was found in the carapace. The ${ }^{239} \mathrm{Pu}$ concentration on a per gram basis, however, was least in the carapace.

3. The estimated whole body radiation dose either to man after ingesting ${ }^{239} \mathrm{Pu}$ in the soft tissues of ten crayfish from the White Oak Creek floodplain or to other predators of those crayfish, including raccoons, owls, or hawks, is inconsequential in comparison with background radiation. 


\section{REFERENCES}

Aarkrog, A. 1971. Radioecological investigations of plutonium in an arctic marine environment. Health Physics 20:31-47.

Auerbach, S. I., et a1. 1977. Transuranium elements in aquatic and terrestrial environments. pp. 131-147. In: Section 8, Environmental Sciences Division Annual Progress Report for period ending September 30, 1976. ORNL-5257. Oak Ridge National Laboratory, Oak Ridge, Tennessee. 309 pp.

Auerbach, S. I., et al. 1978 Actinide elements in aquatic and terrestrial environments. pp. 58-74. In: Sertion 5, Environmental Sciences Division Annual Progress Report for period ending September 30, 1977. ORNL-5365. Oak Ridge National Laboratory, Oak Ridge, Tennessee. 248 pp.

Baricruft, T. A., and T. A. Brindley. 1958. Methods for estimation of size of corn borer populations. Proceedings Tenth International Congress of Entomology 1956(2):1003-1014.

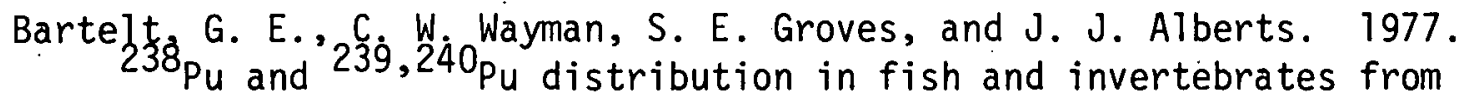
the Great Miami River, Ohio. In: White, M. G., and P. B. Dunaway (eds.), Transuranics in Natural Environments. NV0-178. Nevada Applied Ecology Group, U. S. Dept. of Energy.

Bliss, D. E. 1968. Transition from water to land in decapod crustaceans. Am. Zool. 8:355-392.

Bondietti, E. A., and S. A. Reynolds. 1976. Field and laboratory observations on plutonium oxidation states. In: Ames, L. L. (ed.), Proc. Workshop on Actinide-Sediment Interactions. BNWL-2117.

Bondietti, E. A., S. A. Reynolds, and M. H. Shanks. 1976. Interaction of plutonium with complexing substances in soils and natural waters. pp. 273-286. In: Transuranium Nuclides in the Environment. IAEA-SM-199/51.

Bouchard, R. W. 1972. A contribution to the knowledge of Tennessee crayfishes. Doctoral Dissertation, The University of Tennessee, knoxville. $113 \mathrm{pp}$.

Bouchard, R. W. 1973. A new crayfish of the subgenus Jugicambarus from Tennessee with an emended definition of the subgenus (Astacidae, Decapoda). Am. Midl. Nat. 89(1):103-111. 
Bouchard, R. W. 1974. Geography and ecology of crayfishes of the Cumberland Plateau and Cumberland Mountains, Kentucky, Virginia, Tennessee, Georgia, and Alabama. Part II. The genera Fallicambarus and Cambarus. pp. 255-266. In: Avault, J.W., Jr. (ed.), Freshwater Crayfish. Second International Crayfish Symposium, Baton Rouge, Louisiana.

Bouchard, R. W., and H. H. Hobbs, Jr. 1976. A new subgenus and two new species of crayfishes of the genus Cambarus (Decapoda: Cambaridae) from the southeastern United States. Smithsonian Contributions to Zoology No. 224. Smithsonian Institution Press, Washington. $15 \mathrm{pp}$.

Chase, G. D., and J. L. Rabinowitz. 1962. Principles of Radioisotope Methodology. Burgess Publishing Company, Minneapolis, Minnesota.

Cleveland, J. M. 1970. The Chemistry of Plutonium. Gordan and Breach Science Publishers, Inc., New York.

Craig, R. B., and R. L. Rudd. 1974. The ecosystem approach to toxic chemicals in the biosphere. In: Khan, M. A. Q., and J. P. Bederka (eds.), Survival in Toxic Environments. Academic Press, Inc., New York.

Dahlman, R. C., E. A. Bondietti, and L. D. Eyman. 1976. Biological pathways and chemical behavior of plutonium and other actinides in the environment. pp. 47-80. In: Freidman, A. M. (ed.), Actinides in the Environment. ACS Symposium Series, No. 35. American Chemical Society.

Delaney, M. S., and C. W. Francis. 1978. The relative uptake of Pu-237(IV) and Pu(VI) oxidation states from water by bush beans. Health Physics 34(5):492-494.

Dennel1, R. 1960. Integument and exoskeleton. Vol. 1, Ch. 14. In: Waterman, T. H. (ed.), The Physiology of Crustacea. Academic Press, New York.

Dewees, J. 1972. Geographic variation in the primary burrowing crayfish, Cambarus dubius Faxon and Cambarus carolinus (Erichson) (Decapoda: Astacidae) in Tennessee with notes on ecology and 1 ife history. Master's Thesis, The University of Tennessee, Knoxville.

Erichson, W. F. 1846. Ubersicht der Arten der Gattung Astacus. Archiv fur Naturgeschichte (Berlin) 12(1):86-103.

Eyiliall, L. D., and J. R. Trabalka. 1977. Distribution patterns and transport of plutonium in freshwater environments with emphasis on primary producers. pp. 477-487. In: White, M. G., and P. B. Dunaway (eds.), Transuranics in Natural Environments. NV0-178. Nevada Applied Ecology Group, U. S. Dept. of Energy. 
Francis, C. W. 1973. Plutonium mobility in soil and uptake in plants: A review. J. Environ. Qual. 2(1):67-70.

Guary, J.-C., M. Masson, and A. Fraizier. 1976. In situ preliminary study of plutonium distribution in different tissues and organs of Cancer pagurus (Crustacea: Decapoda) and Pleuronectes platessa (Pisces: Pleuronectidae). Mar. Biol. 36(1): 13-17 (Trans. from French).

Gwinn, J. F., and J. R. Stevenson. 1973. Role of acetylglucosamine in chitin synthesis in crayfish. I. Correlation of $14 \mathrm{C}$-acetylglucosamine incorporation with stages of the molting cycle. Comp. Biochem. Physiol. 45B:769-776.

Hine, G. J., and G. L. Brownel1 (eds.). 1956. Radiation Dosimetry. Academic Press Inc., New York. 932 pp.

Hobbs, H. H., Jr. 1965. A new crayfish of the genus Cambarus from Tennessee with an emended definition of the genus (Decapoda, Astacidae). Proc. Biol. Soc. Wash. 78(33):265-273.

Hobbs, H. H., Jr. 1969. On the distribution and phylogeny of the crayfish genus Cambarus. pp. 93-178. In: Holt, P. C., R. L. Hoffman, and C. W. Hart, Jr. (eds.), The Distributional History of the Biota of the Southern Appalachians. Part I: Invertebrates. Virginia Polytechnic Institute, Research Division Monograph 1.

Hobbs, H. H., Jr. 1970. A new crayfish from the Nashville Basin, Tennessee. Proc. Biol. Soc. Wash. 83(14):161-170.

Hobbs, H. H., Jr. 1972. Crayfishes (Astacidae) of North and Middle America. Biota of Freshwater Ecosystems. Identification Manual No. 9. U. S. Environmental Protection Agency. 173 pp.

Hobbs, H. H., Jr. 1974. Synopsis of the families and genera of crayfishes (Crustacea: Decapoda). Smithson. Contrib. Zool. No. $164.32 \mathrm{pp}$.

Hobbs, H. H., Jr., and R. W. Bouchard. 1973. A new crayfish from the Cumberland River system with notes on Cambarus carolinus (Ertchsun). Proc. Blul. Suc. Wash. 89(5):47-68.

Huner, J. V. 1976. Utilization of crawfishes by North American herons and ibises with preliminary observations on their activity in Louisiana commercial crawfish ponds. Bull. Ecol. Soc. Am. $57(1): 46$.

International Commission on Radiological Protection. 1966. Recommendations of the International Commission on Radiological Protection (adopted September 17, 1965). ICRP Publication 9. Pergamon Press, 0xford. 
Jarrett, A. A. 1946. Statistical methods used in the measurement of radioactivity (some useful graphs). U. S. Atomic Energy Comm. Rept. AECU-262 (Mon P-126). June 17, 1946.

Killough, G. G., and L. R. McKay (compilers). 1976. A methodology for calculating radiation doses from radioactivity released to the environment. ORNL-4992. Oak Ridge National Laboratory, Oak Ridge, Tennessee.

Kocher, D. C. 1977. Nuclear decay data for radionuclides occurring in routine releases from nuclear fuel cycle facilities. ORNL/ NUREG/TM-102. Oak Ridge National Laboratory, Oak Ridge, Tennessee. $110 \mathrm{pp}$.

Momot, W. T. (ca. 1973). Organisms in relation to their environment-crayfish. Department of Zoology and School of Natural Resources, The Ohio State University, Columbus, Ohio.

Momot, W. T., H. Gowing, and P. D. Jones. 1978. The dynamics of crayfish and their role in ecosystems. Am. Midl. Nat. 99(1): $10-35$.

Oakes, T. W., K. E. Shank, and C. E. Easterly. 1976. Natural and man-made radionuclide concentrations in Tennessee soils. pp. 322-333. In: Tenth Midyear Topical Symposium of the Health Physics Society Northeastern New York Chapter.

Passano, L. M. 1960. Molting and its control. Vol. 1, Ch. 15. In: Waterman, T. H. (ed.), The Physiology of Crustacea. Academic Press, New York.

Patten, B. C. (ed.). 1972. Systems Analysis and Simulation in Ecology. Academic Press, New York. 592 pp.

Patzer, R. G. 1976. Concentration factors and transport models for radionuclides in aquatic environments: A literature report. EPA-600/3-76-054. Environmental Monitoring and Support Laboratory, Office of Research and Development, U. S. Environmental Protection Agency.

Penn, G. H. 1950. Utilization of crawfishes by cold-blooded vertebrates in the eastern United States. Am. Midl. Nat. 44(3):643658.

Prins, R. D. 1968. Comparative ecology of the crayfishes Orconectes rusticus and Cambarus tenebrosus in Doe Run, Meade County, Kentucky. International Revue der Gesamten Hydrobiologie $53(5): 667-714$. 
Reichie, D. E. 1967. Radioisotope turnover and energy flow in terrestrial isopod populations. Ecology 48(3):351-366.

Reichle, D. E., P. B. Dunaway, and D. J. Nelson. 1970. Turnover and concentration of radionuclides in food chains. Nucl. Saf. 11(1): 43-55.

Schurr, J. M., and M. N. Stamper. 1962. Model for the accumulation of strontium and calcium by recently molted crayfish (Cambarus longulus longerostris Ort.). Limnol. Oceanogr. $7(4): 4 \overline{74-477 .}$

Schuster, G. A. 1976. A new primary burrowing crayfish of the subgenus Jugicambarus (Decapoda, Cambaridae) from Kentucky, with notes on its life history. Am, Midl. Nat. 95(1):225-230.

Skinner, D. M. 1962. The structure and metabolism of a crustacean integumentary tissue during a molt cycle. Biol. Bull. 123(3): 635-647.

Stevenson, Jr. R. 1969. Sclerotin in the crayfish cuticle. Comp. Biochem. and Physiol. 30:503-508.

Stevenson, J. R. 1974. The molting cycle in the crayfish: Recognizing the molting stages, effects of edcysone, and changes during the cycle. pp. 255-266. In: Avault, J. W., Jr. (ed.), Freshwater Crayfish. Second International Crayfish Symposium, Baton Rouge, Louisiana.

Tanner, J. T. 1964. Preliminary radioecological study of the crayfish of the Oak Ridge area. Unpublished manuscript. Health Physics Division, Oak Ridge National Laboratory, Oak Ridge, Tennessee. $26 \mathrm{pp}$.

Trabalka, J. R., and L. D. Eyman. 1977. Plutonium-237: An important research tool for studies of environmental plutonium kinetics. pp. 489-503. In: White, M. G., and P. B. Dunaway (eds.), Transuranics in Natural Environments. NV0-178. Nevada Applied Ecology Group, U. S. Dept. of Energy.

U. S. Environmental Protection Agency (Code of Federal Regulations, Title 40, Part 190). 1977. Environmental Kadiation Protection Standards for Nuclear Power Operations. Fed. Regist. 42(9), January 13, 1977.

Vanderploeg, H. A., D. C. Parzyck, W. H. Wilcox, J. R. Kercher, and S. V. Kaye. 1975. Bioaccumulation factors for radionuclides in freshwater biota. ORNL-5002. Oak Ridge National Laboratory, Oak Ridge, Tennessee. 222 pp.

Walton, M., and H. H. Hobbs, Jr. 1971. The distribution of certain entocytherid ostracods on their crayfish hosts. Proc. Acad. Nat. Sci. Philadelphia 123(4):87-103. 
Ward, E. E. 1966. Uptake of plutonium by the lobster Homarus vulgaris. Nature 209:625-626.

Wayman, C. W., G. E. Bartelt, and S. E. Groves. 1975. Further investigations of plutonium in aquatic biota of the Great Miami River watershed including the canal and ponds in Miamisburg, Ohio. Radiological and Environmental Research Division Annual Report, 1975. Argonne National Laboratory, Argonne, Illinois. ANL-75-60, Part III.

Wessman, R. A., and L. Leventhal. 1977. Historical review of transuranic analytical methodology. pp. 545-574. In: White, M. G., and P. B. Dunaway (eds.), Transuranics in Natural Environments. NV0-178. Nevada Applied Ecology Group, U. S. Dept. of Energy.

Williams, D. D., N. E. Williams, and H. B. N. Hynes. 1974. Observations on the life history and burrow construction of the crayfish Cambarus fodiens (Cottle) in a temporary stream in southern Ontario. Can. J. Zool. 52(3):365-370. 
THIS PAGE

\section{WAS INTENTIONALLY \\ LEFT BLANK}


APPENDIX A

\section{TRAP SPECIFICATIONS}

Crayfish have reportedly been collected by several methods with varying degrees of success (Bouchard, 1972; Dewees, 1972; Hobbs, 1972; Williams et al., 1974). Some of the techniques include flooding, dissecting, coring, or adding chemicals to the burrow, night collecting, or setting various kinds of conventional traps. However, Dewees learned that no $\underline{\mathbf{C}}$. carolinus were ever captured in such traps. On the floodplain, an occasional juvenile or adult was observed and taken up by hand; other specimens were more difficult to capture.

In such a radioactive habitat, the crayfish could not be exposed by digging. Unless water was flowing readily through the area, specimens were not apt to be found in the open. Before the species was identified, a trap that would not kill the specimen and that would work overnight was desirable.

A new trap was designed to attract and capture an individual crayfish. Figure $A-1$ is an isometric projection of the new trap with each of the features distinctly visible. A dead minnow was attached to the trigger mechanism; when the crayfish entered the trap and pulled on the bait, the flap fell over the burrow entrance and prevented escape.

\section{Materials and Methods}

Cedar was selected because it would withstand water without warping and because it would not be apt to split with age. The different pieces of wood needed to assemble the trap and their sizes have been itemized 


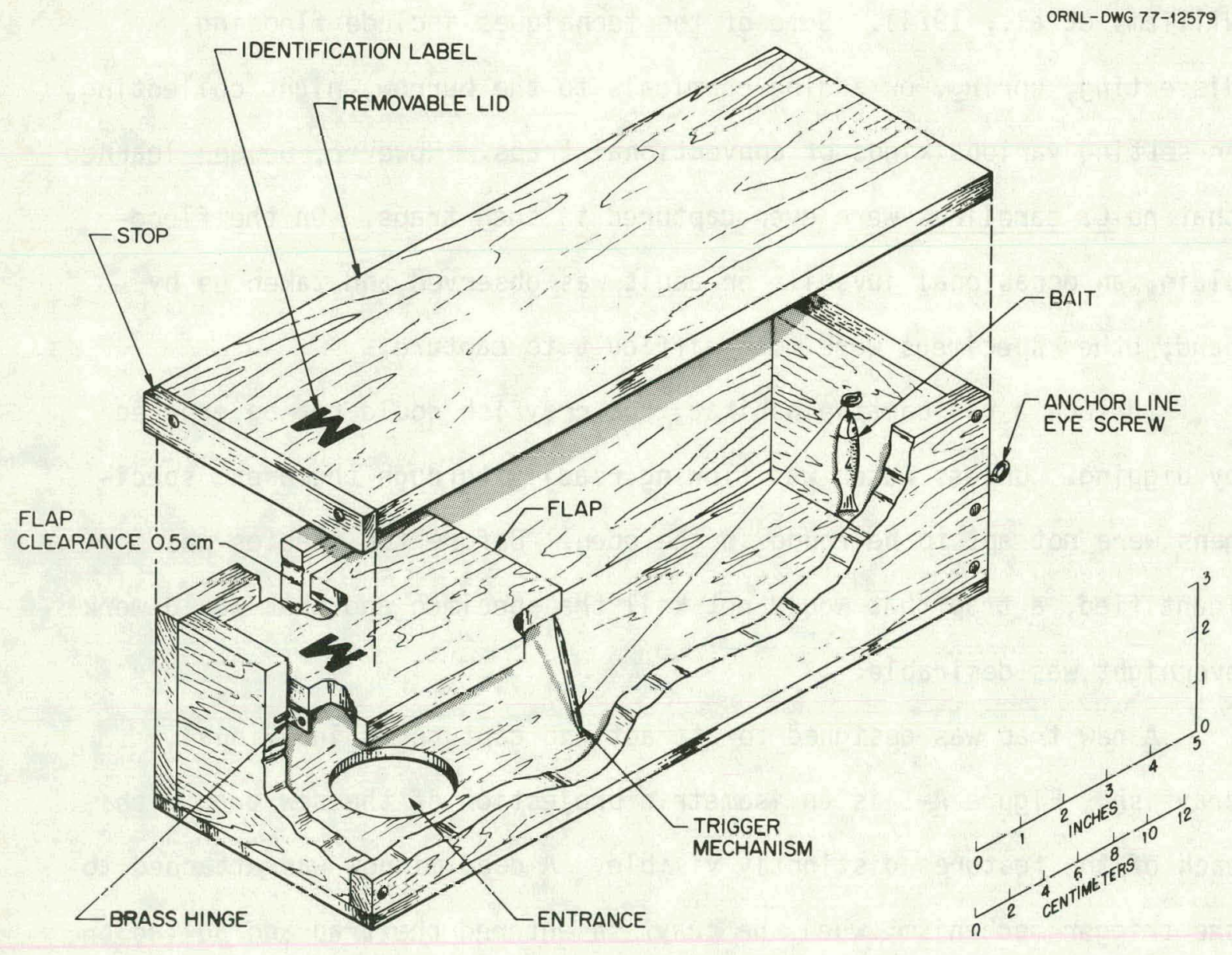

Figure A-1. An isometric projection of the crayfish trap. 
in Table A-1. The bottom piece, with a $5 . \mathrm{cm}$ hole cut into it near one end, had to be very smooth for the trigger mechanism to slide easily. The hardware needed to be either rust resistant or easily replaceable. If the inner eye screw rusted, the crayfish could pull the bait without disturbing the trigger. The outer eye screw provided a point of attachment for a string to tie the trap to a fixed object. The hinge for the flap had to be oiled and placed such that there was adequate clearance from the top of the trap with the flap either up or down.

The trigger mechanism was made from a wooden toothpick tapered to a point at each end, some monofilament line tied near its base, and bait at the other end of the line. The bait was a freshly dead minnow about $4 \mathrm{~cm}$ 1ong. The line was inserted into its mouth to pass out one gill slit, brought over the minnow's back, and inserted into the other

gill slit to pass out the mouth. The line was tied at the mouth with a double knot. The bait was suspended from the inner eye screw, and the toothpick was propped beneath the hinged flap near one corner. If the toothpick was slanted slightly, its base inclined toward the bait, the trigger operated more effectively.

To prevent a predator from knocking off the cover and eating either the bait or the captured crayfish, a brick was placed on top of the closed trap. Identification on the interior and exterior of the trap was helpful.

\section{Results and Comments}

Using prototype traps, capture ranged from 0 to $38 \%$ per day of trapping; the mean capture rate was $14 \%$ per day of trapping. Using hetter traps, for which the probability of escape decreased, capture 
Table A-1. Dimensions of wooden trap pieces

\begin{tabular}{ll}
\hline Description & \multicolumn{2}{l}{ Dimensions $(\mathrm{cm})$} \\
\hline Top cover & $1 \times 13 \times 35$ \\
Stop & $0.5 \times 13 \times 2$ \\
Long sides & $1 \times 9.5 \times 35$ \\
End pleces & $1 \times 9.5 \times 11$ \\
Flap & $1 \times 13 \times 35$ \\
Bottom & $0.5 \times 13 \times 35$ \\
\hline
\end{tabular}


was estimated to maximize about $46 \%$ per day of trapping in a previous $7 y$ untrapped population with curious and hungry adults. An unanticipated result of the trap design and bait was that only adults were captured; no crayfish less than $4.5 \mathrm{~g}$ were trapped.

Success in the trapping effort depended on the freshness of the selected chimneys. For example, if a dried mud chimney was found, and if the burrow opening was inhabited by a spider, the burrow had been abandoned. However, if a chimney was enlarged one day, the capture could almost be guaranteed. Crayfish were not attracted to the trap if the water table was very low or if the bait was frozen.

Advantages. Since the trap was usually damp, the humidity inside was adequate for a crayfish to respire. All specimens were found alive. The trap was useful in capturing a specimen without destroying or altering its burrow habitat. The burrow would have been at least partially ruined with other methods. In most cases, only the radioactive soil of the chimney needed to be handled so that the trap would iie fiat.

Another advantage was that the bait and toothpick could be assembled before going to the field. The amount of gamma radiation dose received was thereby reduced. The bait sets were placed in individual compartments of a rack for convenience in transporting them.

Disadvantages. Traps could be positioned over chimneys only in relatively flat locations. Several openings were on steep banks or under tree roots. Unless a trap could be propped up with a stick securely, in addition to being anchored from above, the trap slipped. 
Some crayfish managed to escape. A few would repair chimneys into the trap; when the mud was piled high enough, the specimen could take the bait and retreat as well. In the prototype traps, several escaped because the length was inadequate; the crayfish were able to return under the flap before it fell. Even in the better traps, if a crayfish on its way to the bait knocked the toothpick, the flap fell, and the animal wriggled backwards to the burrow. 
APPENDIX B

ANALYSIS AND RESULTS OF $239 \mathrm{PU}$ IN CRAYFISH

Techniques for cleaning and preparing crayfish for ${ }^{239} \mathrm{Pu}$ analysis have been assembled below. Discussion will include details of solubilization and concentration with methods for coprecipitation and extraction. Several of the techniques have been used in previous ${ }^{239} \mathrm{Pu}$ analyses of biological samples. Bondietti and Reynolds (1976) assembled procedures and commented on their applicability and merits with respect to valence determinations. Some of those procedures were adapted for this study. A discussion of sequential procedures is included in a review of transuranic analytical methodology written by Wessman and Leventhal (1977).

\section{Cleaning and Dissecting Crayfish}

Trapped crayfish were sealed in plastic bags and frozen. The crayfish were cleaned after being defrosted overnight under refrigeration. They were washed in a solution of Alconox detergent and distilled water and scrubbed with a brush; oily crayfish soaked in the Alconox solution 2 to $3 \mathrm{hr}$. In a beaker of fresh Alconox solution, the crayfish were washed sonically at the highest frequency for $5 \mathrm{~min}$; washes were repeated 3 to 6 times. The crayfish were rinsed with distilled water, allowed to air dry for 15 to $30 \mathrm{~min}$, and inspected for trapped dirt first visually and then microscopically $(50 \mathrm{X})$ with supplementary light. Any dirt was removed with a needle. 
Individual carcasses were weighed and dissected into digestive tracts, soft tissues, and carapaces. Digestive tracts and soft tissues were put into preweighed Pyrex test tubes (25 mm diam); carapace pieces were loosely put into preweighed Pyrex beakers $(250 \mathrm{ml})$. Test tubes and beakers were covered with perforated aluminum foil.

\section{Preparation for Analysis}

Test tubes and beakers were placed in a vented drying oven and dried at $65^{\circ} \mathrm{C}$ for at least $48 \mathrm{hr}$. Results of the $\mathrm{Pu}$ analysis were based on the subsequent dry weight. Tubes and beakers were then placed in a muffle furnace as recorded in Table B-1.

Table B-1. The schedule of furnace temperatures $\left({ }^{\circ} \mathrm{C}\right)$ and the amount of time $(\mathrm{hr})$ to decarbonize and to dry ash prepared samples

\begin{tabular}{cc}
$\begin{array}{c}\text { Temperature } \\
\left({ }^{\circ} \mathrm{C}\right)\end{array}$ & $\begin{array}{c}\text { ( ime } \\
(\mathrm{hr})\end{array}$ \\
\hline 75 & 5 \\
105 & 16 \\
200 & 24 \\
$3 / 5$ & 24 \\
525 & 24 \\
\hline
\end{tabular}




\section{Solubilization and $242 \mathrm{pu}$ Tracer Equilibration}

Wet ashing and most steps of the Pu recovery procedure were performed in a fume hood. Pyrex tubes were set in a wire rack with infrared lamp heat sources over it and aluminum foil underneath it for reflectivity. Pyrex beakers were placed on a large hot plate covered with aluminum foil. Adequate space was maintained around each tube or beaker to permit a watch glass to rest on the rim.

\section{Digestive Tracts and Soft Tissues}

One $\mathrm{ml}$ aliquots of $8 \underline{\mathrm{M} \mathrm{HNO}} 3$ ( 1 to $5 \mathrm{ml}$ total) were added to dissolve the ash, tracer ${ }^{242} \mathrm{Pu}(5 \mathrm{dpm})$ was added, and the samples refluxed for about $30 \mathrm{~min}$. An additional $2 \mathrm{ml}$ of $8 \underline{\mathrm{M} \mathrm{HNO}} 3$ plus 2 drops of $\mathrm{H}_{2} \mathrm{O}_{2}(30 \%)$ were then added. After refluxing about $30 \mathrm{~min}$, $2 \mathrm{ml}$ distilled water were added. In some samples, up to $5 \mathrm{ml} 12 \underline{\mathrm{M}} \mathrm{HCl}$ were added to aid wet digestion. Digestion continued to dryness overnight.

Two $\mathrm{ml} 8 \underline{\mathrm{M} \mathrm{HNO}}{ }_{3}$ were added, the acid solution centrifuged, and the supernatant transferred to a plastic, screw cap centrifuge tube. Several $2 \mathrm{ml} 1 \underline{\mathrm{M}} \cdot \mathrm{HNO}_{3}$ aliquots were used to rinse the digestion test tube and precipitate. After centrifuging, the supernatant was transferred to the plastic tube for qualitative transfer of the solubilized material.

\section{Carapace}

Ashes were moistened with $5 \mathrm{ml}$ distilled water before $5 \mathrm{ml} 16 \underline{\mathrm{M}}$ $\mathrm{HNO}_{3}$ and tracer ${ }^{242} \mathrm{Pu}(5 \mathrm{dpm})$ were added. After refluxing about 30 min, $5 \mathrm{ml} 8 \underline{\mathrm{M}} \mathrm{HNO}_{3}$ and $2 \mathrm{ml} \mathrm{H}_{2} \mathrm{O}_{2}$ (30\%) were added. After 


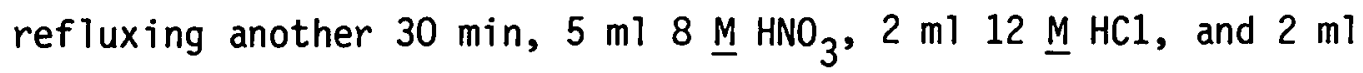
$\mathrm{H}_{2} \mathrm{O}_{2}$ were added to continue the process in aqua regia. Equal. volumes of the three agents were added whenever the reaction had subsided for about 30 min until digestion was complete.

Contents of the beaker were transferred to a plastic centrifuge tube, centrifuged $5 \mathrm{~min}$, and the supernatant transferred to a plastic beaker $(100 \mathrm{ml})$. The Pyrex beaker was washed with $2 \mathrm{ml} 1 \underline{\mathrm{M}} \mathrm{HNO}_{3}$, the acid transferred to the plastic tube, and centrifuged. The supernatants were combined. The pellet in the plastic tube was washed with $1 \underline{M}$ $\mathrm{HNO}_{3}$; after centrifuging, the supernatant was transferred to the plastic beaker.

A magnetic stirring bar was placed in the plastic beaker which was on a magnetic stirrer. While stirring, 4 drops of $5 \underline{M}$ hydroxylamine hydrochloride and 3 drops of crystal violet indicator were added. Concentrated $\mathrm{NH}_{4} \mathrm{OH}$ was then added until the indicator turned blue $(\mathrm{pH}=2)$.

\section{Concentration}

After wet digestion of the ashed digestive tract and soft tissue samples and equilibration of the ${ }^{242} \mathrm{Pu}$ tracer, $\mathrm{Pu}$ from the samples was concentrated on $\operatorname{PrF}_{3}$ precipitate. Four $\mathrm{mg}$ of $\operatorname{Pr}\left(\mathrm{NO}_{3}\right)_{3}$ were added to the solubilized samples, and distilled water was added to make a $13 \mathrm{ml}$ volume. With a plastic pipette, $1 \mathrm{ml} 29 \mathrm{M} \mathrm{HF}$ was added, the tube capped, and the contents mixed. The $\operatorname{PrF}_{3}$ precipitate that formed concentrated the Pu from the solution. After centrifuging to separate 
the precipitate thoroughiy, it was further analyzed as described in the section on extraction.

For the carapace samples, the large Ca content dictated that a fractional $\mathrm{CaF}_{2}$ precipitation step be used to carry $\mathrm{Pu}$ in the presence of $\mathrm{Ca}$. To the solubilized carapace samples, $2 \mathrm{mg} \operatorname{Pr}\left(\mathrm{NO}_{3}\right)_{3}$ and saturated $\mathrm{NaF}$ solution were added until a visible $\mathrm{CaF}_{2}$ precipitate formed. This precipitate was allowed to stand overnight. After centrifuging to separate the precipitate, it was further analyzed as described in the section on extraction.

\section{Extraction}

Digestive Tracts and Soft Tissues

After $15 \mathrm{~min}$, the $\mathrm{PrF}_{3}$ precipitate (carrying $\mathrm{Pu}$ ) was washed with $1 \mathrm{ml} 1 \underline{\mathrm{M} H F}-1 \underline{\mathrm{M}} \mathrm{HNO}_{3}$, centrifuged, and the supernatant removed. The $\mathrm{PrF}_{3}$ pellet was dissolved with $0.5 \mathrm{ml} 1 \mathrm{M} \mathrm{HNO}{ }_{3}$-saturated $\mathrm{H}_{3} \mathrm{BO}_{4}$ solution, and was transferred to a glass extraction vial. Two drops of $3 \underline{\mathrm{M} \mathrm{NaNO}}{ }_{2}$ were added to the vial which was swirled and allowed to stand $10 \mathrm{~min}$. One $\mathrm{ml}$ of $0.5 \mathrm{M}$ TTA in $0-X y l e n e$ was added to the vial, which was shaken $10 \mathrm{~min}$ and allowed to stand overnight. Most of the TTA-xylene phase was removed after centrifuging and transferred to a small test tube. A $0.5 \mathrm{ml}$ aliquot of $0.5 \mathrm{M}$.TTA-xylene was added to the vial which was shaken 10 min and centrifuged. The TTA-xylene phase was removed and combined with the first extraction. 


\section{Carapace}

After the overnight $\mathrm{CaF}_{2}$ precipitation, samples were transferred to tubes and centrifuged $5 \mathrm{~min}$. The pellet was washed with $5 \mathrm{ml} 1 \underline{\mathrm{M}}$ $\mathrm{HNO}_{3^{-1}} \underline{M F}$, the tube centrifuged, an the supernatant discarded. Ten ml 1 M $\mathrm{HNO}_{3}$-saturated $\mathrm{H}_{3} \mathrm{BO}_{4}$ solution was added to each sample which was put into a hot water bath for $10 \mathrm{~min}$, mixed, cooled, and centrifuged. Five drops of $5 \underline{M}$ hydroxylamine hydrochloride and $5 \mathrm{ml} \mathrm{HF}$ were added. The precipitate that formed $\left(\mathrm{PrF}_{3}\right.$ and $\left.\mathrm{CaF}_{2}\right)$ contained only a fraction of the original $\mathrm{Ca}$. After centrifuging, the pellet was washed twice with $1 \underline{M}^{-1} \mathrm{HNO}_{3}-1 \underline{M} \mathrm{HF}$. To dissolve the pellet, $1 \mathrm{ml} 2 \underline{M}$ $\mathrm{Al}\left(\mathrm{NO}_{3}\right)_{3}$ and $1 \mathrm{ml} 2 \mathrm{M} \mathrm{HNO}_{3}$ were added, and the tubes stood overnight.

After $2 \mathrm{ml}$ of $0.5 \mathrm{M}$ TTA-xylene were added, the samples were shaken 30 min, centrifuged, and the supernatant transferred to an extraction vial. A $0.5 \mathrm{ml}$ aliquot of TTA-xylene was used to extract the solution again, and the supernatant was combined with that from the first extraction.

The combined TTA-xylene phases were washed with $4 \mathrm{ml} 1 \mathrm{M} \mathrm{HNO}_{3}$. The $\mathrm{Pu}$ was then back-extracted from the TTA-xylene with $0.75 \mathrm{ml} 8 \underline{\mathrm{M}}$ $\mathrm{HNO}_{3}$ overnight. The back-extraction was necessary to decontaminate the sample from a large amount of Fe that extracted into the TTA-xylene from the solution. After 3 drops of $\mathrm{H}_{2} \mathrm{O}_{2}$ were added, the liquid was dried in a sand bath under an infrared lamp. Dried samples were then dissolved in $1.5 \mathrm{ml} 0.5 \mathrm{M} \mathrm{HNO}_{3}$. Samples ready at this step were extracted two times with TTA-xylene and plated as described in the next 
section on counting. Samples still having an excess of Fe had to be decontaminated further with a back-extraction time of 20 min.

\section{Preparation and Counting}

The TTA-xylene phase was spotted onto a stainless steel planchet that was centered over a metal washer on a hot plate. Care was taken to spread the liquid uniformly in the center of the planchet. The planchet was heated to a dull red, cooled, and counted.

Samples were measured by alpha spectroscopy using a silicon surface-barrier detector integrated with a multi-channel analyzer. Results of the analys is for contaminated and control crayfish and the statistical data in conjunction with the results are compiled in Table B-2. Counting time was a minimum of 24 hours. Background was established by using a clean stainless steel planchet in the detector for $26.6 \mathrm{hr}$. No counts were detected during that time for either $239,240 \mathrm{Pu}$ or ${ }^{242} \mathrm{Pu}$ alpha energy regions; only two counts were detected in the region for ${ }^{238} \mathrm{Pu}$. For the digestive tracts, soft tissues, and carapaces of the control crayfish, the ${ }^{239} \mathrm{Pu}$. counts are statistically greater than the background ${ }^{239} \mathrm{pu}$ counts at the 0.05 level of significance, using a nomogram prepared by Jarrett (1946). 
Table B-2. Compilation of analytical and statistical data for contaminated and . control crayfish from three study sites for two years

\begin{tabular}{|c|c|c|c|c|c|}
\hline Crayfish & Data set & Subset & $\begin{array}{l}\text { Digestive } \\
\text { tract }\end{array}$ & $\begin{array}{l}\text { Soft } \\
\text { tissues }\end{array}$ & Carapace \\
\hline \multirow[t]{5}{*}{ Contaminated ${ }^{\mathrm{a}}$} & $242 p_{u}$ counts & $\begin{array}{l}1_{b, c, d}^{b, c, e} \\
2 b, c, f \\
3 b, c, f \\
4 b, c, g \\
5^{h, c, j} \\
6 b, j, j \\
7_{h, j, j} \\
8 h, j, k \\
9^{h, j, f}\end{array}$ & $\begin{array}{r}388 \\
1020 \\
944 \\
981 \\
1381 \\
1136 \\
1057 \\
4150 \\
657\end{array}$ & $\begin{array}{r}1297 \\
1750 \\
1296 \\
1099 \\
1065 \\
1148 \\
568 \\
2153 \\
1131\end{array}$ & $\begin{array}{r}1376 \\
903 \\
266 \\
882 \\
2255 \\
419 \\
1697 \\
1025 \\
535\end{array}$ \\
\hline & $239 \mathrm{pu}$ counts & $\begin{array}{l}1 \\
2 \\
3 \\
4 \\
5 \\
6 \\
7 \\
8 \\
9\end{array}$ & $\begin{array}{r}505 \\
631 \\
566 \\
963 \\
180 \\
338 \\
221 \\
1155 \\
282\end{array}$ & $\begin{array}{r}867 \\
286 \\
300 \\
564 \\
42 \\
144 \\
117 \\
40 \\
133\end{array}$ & $\begin{array}{r}3627 \\
1261 \\
533 \\
2511 \\
365 \\
249 \\
2050 \\
160 \\
132\end{array}$ \\
\hline & ${ }^{239} \mathrm{pu} \quad(\mathrm{dpm})$ & $\begin{array}{l}1 \\
2 \\
3 \\
4 \\
5 \\
6 \\
7 \\
8 \\
9\end{array}$ & $\begin{array}{l}7.470 \\
3.093 \\
2.998 \\
4.908 \\
0.652 \\
1.488 \\
1.045 \\
1.392 \\
2.146\end{array}$ & $\begin{array}{l}3.342 \\
0.817 \\
1.157 \\
2.566 \\
0.197 \\
0.627 \\
1.030 \\
0.093 \\
0.588\end{array}$ & $\begin{array}{r}13.180 \\
6.982 \\
10.019 \\
14.235 \\
0.809 \\
2.971 \\
6.040 \\
0.780 \\
1.234\end{array}$ \\
\hline & mass $(g)$ & $\begin{array}{l}1 \\
2 \\
3 \\
4 \\
5 \\
6 \\
7 \\
8 \\
9\end{array}$ & $\begin{array}{l}0.489 \\
0.755 \\
0.271 \\
1.339 \\
0.455 \\
0.450 \\
0.446 \\
0.166 \\
0.246\end{array}$ & $\begin{array}{l}1.261 \\
1.742 \\
0.842 \\
2.242 \\
0.701 \\
0.632 \\
1.231 \\
0.371 \\
0.549\end{array}$ & $\begin{array}{r}9.545 \\
11.441 \\
7.445 \\
17.897 \\
5.581 \\
5.901 \\
9.136 \\
2.843 \\
4.206\end{array}$ \\
\hline & ${ }^{239} \mathrm{pu}_{\mathrm{u}}\left(\mathrm{dpm} \mathrm{g}^{-1}\right)$ & $\begin{array}{l}1 \\
2 \\
3 \\
4 \\
5 \\
6 \\
7 \\
8 \\
9\end{array}$ & $\begin{array}{r}15.277 \\
4.097 \\
11.062 \\
3.666 \\
1.432 \\
3.306 \\
2.344 \\
8.383 \\
8.724\end{array}$ & $\begin{array}{l}2.651 \\
0.469 \\
1.375 \\
1.145 \\
0.281 \\
0.992 \\
0.837 \\
0.250 \\
1.071\end{array}$ & $\begin{array}{l}1.381 \\
0.610 \\
1.346 \\
0.795 \\
0.145 \\
0.504 \\
0.661 \\
0.275 \\
0.293\end{array}$ \\
\hline
\end{tabular}


Table B-2 (continued)

\begin{tabular}{|c|c|c|c|c|c|}
\hline Crayfish & Data set & Subset & $\begin{array}{l}\text { Digestive } \\
\text { tract }\end{array}$ & $\begin{array}{l}\text { Soft } \\
\text { tissues }\end{array}$ & Carapace \\
\hline & $\pm S^{1}\left(\mathrm{dpm} \mathrm{g} g^{-1}\right)$ & $\begin{array}{l}1 \\
2 \\
3 \\
4 \\
5 \\
6 \\
7 \\
8 \\
9\end{array}$ & $\begin{array}{l}0.680 \\
0.163 \\
0.465 \\
0.118 \\
0.107 \\
0.180 \\
0.158 \\
0.247 \\
0.520\end{array}$ & $\begin{array}{l}0.090 \\
0.028 \\
0.079 \\
0.048 \\
0.043 \\
0.083 \\
0.077 \\
0.040 \\
0.093\end{array}$ & $\begin{array}{l}0.023 \\
0.017 \\
0.058 \\
0.016 \\
0.008 \\
0.032 \\
0.015 \\
0.022 \\
0.026\end{array}$ \\
\hline & $\begin{array}{l}0.05 \text { Level of } \\
\text { significance } \\
(\%) \text { m }\end{array}$ & $\begin{array}{l}1 \\
2 \\
3 \\
4 \\
5 \\
6 \\
7 \\
8 \\
9\end{array}$ & $\begin{array}{r}8.72 \\
7.80 \\
8.24 \\
6.32 \\
14.61 \\
10.66 \\
13.18 \\
5.77 \\
11.67\end{array}$ & $\begin{array}{r}6.66 \\
11.59 \\
11.32 \\
8.25 \\
30.24 \\
16.33 \\
18.12 \\
30.99 \\
17.00\end{array}$ & $\begin{array}{r}3.25 \\
5.52 \\
8.49 \\
3.91 \\
10.26 \\
12.42 \\
4.33 \\
15.50 \\
17.06\end{array}$ \\
\hline Control ${ }^{n}$ & $\begin{array}{l}{ }^{242} \mathrm{pu} \text { counts } \\
239 \mathrm{pu} \text { counts } \\
239 \mathrm{pu}(\mathrm{dpm}) \\
\text { mass }(\mathrm{g}) \\
239 \mathrm{pu}\left(\mathrm{dpm} \mathrm{g} \mathrm{g}^{-1}\right) \\
\pm \mathrm{s}^{1}(\mathrm{dpm} \mathrm{g})\end{array}$ & & $\begin{array}{l}1214 \\
5 \\
0.021 \\
0.473 \\
0.044 \\
0.0198\end{array}$ & $\begin{array}{l}982 \\
6 \\
0.031 \\
2.220 \\
0.014 \\
0.0057\end{array}$ & $\begin{array}{l}1646 \\
16 \\
0.049 \\
14.308 \\
0.0034 \\
0.00086\end{array}$ \\
\hline
\end{tabular}

${ }^{a}$ Footnotes $b$ through $k$ apply to all corresponding subsets for contaminated crayfish.

${ }^{b}$ Site 1 .

$d_{n}=4$.

$f_{n}=2$.

hite 2 .

$j_{1977 .}$. $c_{1976 .}$

$e_{n}=5$.

$g_{n}=7$.

$i_{n}=3$.

$k_{n}=1$.

$168.27 \%$.

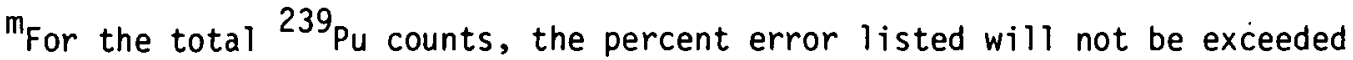
in $95 \%$ of the observations.

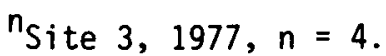


THIS PAGE

WAS INTENTIONALLY

LEFT BLANK 


\section{APPENDIX C \\ CHARACTERISTICS OF $237 \mathrm{PU}$ AND OTHER PU ISOTOPES}

Physical Characteristics and Production of $237 \mathrm{Pu}$

Physical characteristics of $\mathrm{Pu}$ isotopes used during the course of the investigation have been listed for comparison in Table C-1. The half-life of ${ }^{237} \mathrm{Pu}$ is the shortest of those 1isted; its specific activity is the greatest of those listed.

Scientists in the Operations Division (ORNL) made ${ }^{237} \mathrm{Pu}$ at the Isochronous Cyclotron by means of helium ion bombardment of uranium-235. Alpha particles with an energy of 35.9 Mev were used such that

$$
{ }_{92}^{235} \mathrm{U}+{ }_{2}^{4} \mathrm{He} \rightarrow{ }_{94}^{237} \mathrm{Pu}+2 \mathrm{n} .
$$

Trace quantities of ${ }^{236} \mathrm{Pu}$ contaminated the product.

$$
\text { 237pu Citrate }
$$

Uptake of ${ }^{237} \mathrm{Pu}$ was enhanced using sodium citrate as the chelatiny agent in a gavage study (Trabalka and Eyman, 1977). The net negative charge of the plutonium citrate complex permits penetration of the digestive tract membrane (Cleveland, 1970) in channel catfish. The complex is unstable in metabolic systems. With an intraperitoneal injection, maximum retention by a minnow or bluegill would be achieved. 
Table C-1. Comparison of some physical characteristics of $\mathrm{Pu}$ isotopes used in this investigation

\begin{tabular}{|c|c|c|c|c|}
\hline Isotope & $\begin{array}{c}\text { Principal } \\
\text { mode of } \\
\text { decay }\end{array}$ & $\begin{array}{l}\text { Energy } \\
\text { Mev }\end{array}$ & Half-life & $\begin{array}{l}\text { Specific } \\
\text { activity } \\
\text { Ci g-1 }\end{array}$ \\
\hline${ }^{237} \mathrm{Pu}$ & $\gamma$ & $\begin{array}{l}0.0264 \\
0.0758\end{array}$ & $45.6 \mathrm{~d}$ & $1.219 \times 10^{4}$ \\
\hline${ }^{238} \mathrm{Pu}$ & $\alpha$ & $\begin{array}{l}5.499 \\
5.456\end{array}$ & $87.8 y$ & $1.756 \times 10^{1}$ \\
\hline${ }^{239} \mathrm{Pu}$ & $\alpha$ & $\begin{array}{l}5.155 \\
5.143 \\
5.105\end{array}$ & $2.44 \times 10^{4} y$ & $6.191 \times 10^{-2}$ \\
\hline${ }^{240} \mathrm{Pu}$ & $\alpha$ & $\begin{array}{l}5.168 \\
5.123\end{array}$ & $6.54 \times 10^{3} y$ & $2.279 \times 10^{-1}$ \\
\hline${ }^{242} \mathrm{Pu}$ & $\alpha$ & $\begin{array}{l}4.900 \\
4.856\end{array}$ & $3.87 \times 10^{5} y$ & $3.855 \times 10^{-3}$ \\
\hline
\end{tabular}




\section{Acquisition and Preparation}

Isotope characteristics. The concentration of the liquid was $1.4 \mu \mathrm{Ci}{ }^{237} \mathrm{Pu} \mathrm{ml}{ }^{-1}$ in $1.0 \underline{\mathrm{N}} \mathrm{HCl}$ as received.

Dilution. The desired concentration of ${ }^{237} \mathrm{Pu}$ citrate complex for a $50 \lambda$ intraperitoneal injection was $0.01 \mu \mathrm{Ci}{ }^{237} \mathrm{Pu}$ in $10^{-3} \mathrm{M}$ sodium citrate solution. Actual dilution was $0.0088 \mu \mathrm{Ci}{ }^{237} \mathrm{Pu}$ in $50 \lambda$. The activity in $50 \lambda$ was $1.95 \times 10^{4} \mathrm{dpm}$. 
THIS PAGE

\section{WAS INTENTIONALLY \\ LEFT BLANK}




\section{APPENDIX D \\ GLOSSARY OF TERMS}

abdominal segment

a]pha

aqua regia

areola

carapace

chela ( $p 1$. chelae)

CR six distinct sclerotized segments that bear the pleopods, telson, and uropods

positively charged particles emitted with an amount of energy characteristic of the parent nuclide; identical with the nuclei of helium atoms

liquid composed of $\mathrm{HNO}_{3}$ and $\mathrm{HCl}$. With $\mathrm{H}_{2} \mathrm{O}_{2}$, it was used to digest the carapace. region of the dorsal surface of the thoracic carapace delimited by the cervical groove, the caudal edge of the cephalothorax, and the branchiocardiac grooves

biological half-life the time required for $50 \%$ of an administered radionuclide to be eliminated from the body (or an organ or section of living tissue) in uncontaminated surroundings; $T_{b}$ the thoracic carapace, antennae, eyes, chelae, pereiopods, abdominal segment, pleopods, telson, and uropods

claw; terminal segment of the first three pairs of pereiopods concentration ratio (unitless) 
Curie (Ci)

digestive tract

$\mathrm{dpm}$

ecdysis

exuviae

gamma rays

isotopes

N

nuclide

pereiopods

pleopods

$\mathrm{Pu}$ (IV)

$\mathrm{Pu}(\mathrm{VI})$ that quantity of radioactive material having associated with it $3.7 \times 10^{10}$ disintegrations per second; $n C i=10^{-9} \mathrm{Ci} ; \mathrm{pCi}=10^{-12} \mathrm{Ci}$

esophagus, stomach, and intestine disintegrations (nuclear transformations) per minute; $1 \mathrm{pC} i=2.22 \mathrm{dpm}$.

molting phenomenon; shedding of the carapace the cast exoskeleton fragments

short wavelength $\left(10^{-9}\right.$ to $\left.10^{-12} \mathrm{~cm}\right)$ electromagnetic radiation of nuclear origin emitted with energies characteristic of the parent nuclide

the time required for a radioactive substance to lose $50 \%$ of its activity by decay; $t_{1 / 2}$ nuclides containing the same number of protons but different numbers of neutrons and having identical chemical properties

$6.02 \times 10^{23}$ /atomic mass

each species of atom characterized by a fixed number of protons and neutrons in its nucleus serially homologous appendages of the thorax serially homologous biramous appendages of the abdomen

plutonium in the +4 oxidation state plutonium in the +6 oxidation state 
punctations

radioactive decay

radionuclide

soft tissues

specific activity

standard

telson

thoracic carapace

tracer

transuranic element TTA

tubercles

uropods small pits or depressions in the carapace surface disintegration of the nucleus of an unstable element by the spontaneous emission of charged particles and/or photons

a radioactive isotope; radioisotope includes gills, viscera (except intestine), muscle, and membranes

$\lambda N ; 0.693 \mathrm{~N} / \mathrm{t}_{1 / 2}$; disintegrations per unit time/unit mass

a known amount of radioisotope in an appropriate geometry to serve as a basis for comparison with radioactive samples median postabdominal segment of the tail fan exoskeleton covering the cephalothorax an isotope incorporated into a sample to make possible the observation of the course of that element through some biological, chemical, or physical process(es).

an element whose atomic number is greater than 92 2-Thenoyltrifluoroacetone low, rounded eminences of the carapace postabdominal biramous segments on either side of the telson in the tail fan 
ORNL/TM-6702

\section{INTERNAL DISTRIBUTION}

1-17. S. I. Auerbach

18. B. G. Blaylock

19. M. A. Bogle

20. E. A. Bondietti

21. J. N. Brantley

22. R. W. Brocksen

23. D. K. Cox

24-33. R. B. Craig

34-43. M. S. Delaney, Bldg. 1505

44. L. L. Dye

45. L. D. Eyman

46. C. W. Francis

47. C. T. Garten

48. J. W. Huckabee

49. J. R. Jones

50. R. E. Millemann

51. H. Postma
52. D. E. Reichle

53. C. R. Richmond

54. 0. M. Sealand

55. M. H. Shanks

56. D. M. Skinner

57. E. G. Struxness

58. J. S. Suffern

59. T. Tamura

60. J. R. Trabalka

61. J. P. Witherspoon

62. ESD Library

63. Biology Library

64-65. Central Research Library

66-67. Laboratory Records Dept.

68. Laboratory Records, ORNL-RC

69. ORNL Y-12 Technical Library

70. ORNL Patent Office

\section{EXTERNAL DISTRIBUTION}

71. D. C. Adriano, Savannah River Ecology Laboratory, Drawer E, Aiken, SC 29801

72. J. J. Alberts, Savannah River Ecology Laboratory, Drawer E, Aiken, SC 29801

73. A. Covitch, Zoology Dept., University of OKlahoma, Norman, OK 73019

74-83. R. C. Dahlman, Office of Environmental Research, DOE, Washington, DC 20545

84. P. B. Dunaway, Bioenvironmental Sciences Division, Nevada Operations Office, Las Vegas, NV 89114

85. R. Franklin, Office of Environmental Research, DOE, Washington, Dr. 20545

86. T. E. Hakonson, Los Alamos Scientific Laboratory, Los Alamos, NM 87545

87. J. L. Liverman, Office of Environmental Research, DOE, Washington, DC 20545

88. R. J. Mobley, Savannah River Ecology Laboratory, Drawer E, Aiken, SC 29801

89. D. Paine, 202 S Building, 200 West Area, Rockwe 11 Hanford Operations, Richland, WA 99352

90. P. R. Pearson, Biology Dept., Rhode Is land College, Providence, RI 02908

91. E. M. Romney, University of California at Los Angeles, Los Angeles, CA 90024

92. R. G. Schreckhise, Battelle-Pac ific Northwest Laboratory, P.0. Box 999, Richland, WA 99352 
93. H. H. Shugart, Research School of Biological Sciences, Dept. of Environmental Biology, The Australian National University, P.0. Box 4, Canberra, A.C.T. 2600, Australia

94. M. H. Smith, Savannah River Ecology Laboratory, Drawer E, Aiken, SC 29801

95. J. Swinebroad, Office of Environmental Research, DOE, Washington, DC 20545

96. J. T. Tanner, Graduate Program in Ecology, University of Tennessee, Knoxville, TN 37916

97. J. H. Thorpe, Savannah River Ecology Laboratory, Drawer E, Aiken, SC 29801

98. R. L. Watters, Office of Environmental Research, DOE, Washington, DC 20545

99. F. W. Whicker, Colorado State University, Fort Coll1ns, co 80521

100. Office of Assistant Manager, Energy Research and Development, UUE-URU

101-127. Technical Information Center, Oak Ridge, TN 37830 